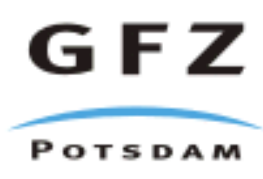

Originally published as:

Muñoz, G., Mateus, A., Pous, J., Heise, W., Santos, F. M., Almeida, E. (2008): Unraveling middle-crust conductive layers in Paleozoic Orogens through 3D modeling of magnetotelluric data: The Ossa-Morena Zone case study (SW Iberian Variscides). - Journal of Geophysical Research, 113, B06106, 1-23

DOI: $10.1029 / 2007 J B 004987$. 


\title{
Unraveling middle-crust conductive layers in Paleozoic Orogens through 3D modeling of magnetotelluric data; the Ossa-Morena Zone case study (SW Iberian Variscides)
}

\author{
Gerard Muñoz ${ }^{(1,+}$, Antonio Mateus ${ }^{(2}$, Jaume Pous ${ }^{(1}$, Wiebke Heise ${ }^{(1, *}$, Fernando Monteiro \\ Santos $^{(3}$, Eugenio Almeida ${ }^{(4}$ \\ ${ }^{(1}$ Departament de Geodinàmica i Geofísica. Universitat de Barcelona. Martí Franquès s/n, 08028 Barcelona, Spain \\ (2 Departamento de Geologia and CEGUL, Faculdade de Ciências da Universidade de Lisboa, C6, Piso 4, Campo Grande, \\ 1749-016 Lisbon, Portugal \\ (3 Faculdade de Ciências da Universidade de Lisboa, CGUL-IDL, C8, Piso 6, Campo Grande, 1749-016 Lisbon, Portugal \\ ${ }^{(4}$ Instituto Politécnico de Tomar, Escola Superior de Tecnología de Tomar, 2300 Tomar, Portugal \\ ${ }^{+)}$Now at: GeoForschungsZentrum Potsdam. Telegrafenberg, 14473 Potsdam, Germany \\ *) Now at: GNS Science. PO Box 30368, Lower Hutt, New Zealand.
}

\section{Abstract}

In recent years a number of magnetotelluric (MT) surveys have been carried out in the southern branch of the Iberian Variscan Massif, namely in the Ossa Morena Zone (OMZ) and its neighboring areas, the South Portuguese Zone (SPZ) and the Central Iberian Zone (CIZ), in order to determine the geoelectrical structure of this transpressive orogen and gain insight into its internal architecture. New MT data collected across the OMZ complete a dense database that covers the whole belt and its boundaries. This paper presents an integrative three-dimensional model of the available MT data from the apparent resistivities (four components), impedance phases and geomagnetic transfer functions from 61 stations. Given the location of the study area, near the Atlantic Ocean, coast effect on the data was analyzed as well as the stability of the mesh due to the strong resistivity contrasts. A mesh of $80 \mathrm{x} 77 \mathrm{x}$ 76 cells was finally used, with an average cell size of $4 \times 4 \mathrm{~km}$ in the horizontal direction, and increasing thickness in the vertical direction from $25 \mathrm{~m}$ in the shallower layers to $5 \mathrm{~km}$ in the deepest ones. The most striking feature is, in addition to the conductive anomalies associated with the sutures between the SPZ-OMZ and the OMZ-CIZ, a conductive layer which spans the whole Ossa Morena mid- to lower crust. The top of this conductive layer is interpreted as 

crucial for the interpretation of the conductivity models obtained. pile. crustal structure

\section{Introduction}

a major décollement between the granulitic basement and the overlying meta-sedimentary

Keywords: Magnetotellurics, three-dimensional modeling, transpressive orogen, SW Iberia

The presence of mid-crustal conductive layers is known in many different geological settings. Regardless of the actual conductivity distribution, the available data show that a general conductivity pattern with depth is apparent: moderately to highly conductive shallow levels above highly resistive intermediate crustal layers beneath which conductivity increases again. (e.g., Egbert and Booker, 1992; Jones 1998, Eisel and Haak, 1999; Wannamaker, 2000). On the other hand, discontinuous conductive layers are frequently found within many middle crust resistive zones (e.g., Wannamaker et al., 2002; Tauber et al., 2003). In this context, the limited amount of interstitial aqueous fluids and the physical properties of minerals stable at intermediate continental crust levels can account for the conductive behavior. The conductive layers are therefore interpreted as related to important structural features (such as regional detachments) and/or particular rock compositions, probably enriched in fluid-deposited graphite and in solid carbon interconnected particles, either amorphous or as graphite (Monteiro Santos et al., 2002), or even in interconnected sulphides (Jones et al., 1997; Evans et al., 2005). The combination of these factors can therefore contribute to develop the particular conductivity distribution, and understanding the role played by each component is 
In SW Iberia, an important segment of the Variscan fold-thrust belt can be characterized in

60 detail, comprising three main geotectonic units: the Ossa Morena Zone (OMZ), the Central Iberian Zone (CIZ) and the South Portuguese Zone (SPZ). The OMZ corresponds to the internal continental segment of SW Iberian Variscides, and a number of MT surveys have been carried out in the last decade (Monteiro Santos el al., 1999; Almeida et al., 2001, 2005; Pous et al., 2004; Muñoz et al., 2005) to obtain data on: (1) the characterization of the electrical conductivity distribution of the whole crust in this transpressive orogen; (2) the detection of the tectonic structures responsible for the $\mathrm{OMZ}$ architecture, namely the main fault zones and décollements; and (3) the depiction of the north and south boundaries of the OMZ in depth. In the present work, new data complete a dense MT database in the SW Iberian Peninsula that was interpreted by three-dimensional (3D) forward modeling. The 3D model allows us to obtain an overall view of the conductivity distribution for the whole OMZ and its complex borders. Additionally, by considering together the geological and geophysical features, the role played by décollement tectonics in strain partitioning within the lithosphere during the SW Iberian Variscides development will be discussed. inversion algorithms have been published (e.g. Mackie and Madden, 1993; Sasaki, 2004;

81 Avdeev, 2005; Siripunvaraporn et al., 2005) these are applied only in simple resistivity 
complex three-dimensional model, both in terms of area covered and complexity of the modeled structures.

\section{The Ossa Morena Zone case study}

The Iberian Massif represents a well preserved fragment of the Variscan basement, allowing characterization of the most complete geotraverse through the Variscan Fold Belt in Europe (Ribeiro, 1981; Matte, 1986; Franke, 1989). It comprises different zones, as depicted in Fig. 1a, divided according to their lithostratigraphic and structural features, and bounded either by major tectonic contacts or narrow belts with distinctive geological characteristics (Lötze, 1945; Julivert et al., 1974, 1980; Farias et al., 1987; Franke, 2000). In this framework, the internal continental segment of the SW Iberian Variscides corresponds to the OMZ, placed between the CIZ, to the north, and the SPZ, to the south. Using the concept of "Tectonostratigraphic Terranes” introduced by Coney et al. (1980), a somewhat different zoning for the SW Iberian Variscides emerges, as proposed by Quesada (1991). Here, the OMZ and CIZ form the Iberian Terrane which, to the south, is brought in contact with the South-Portuguese Terrane through two assembled exotic terranes known as the Beja-Acebuches Ophiolite Complex (BAOC) and the Pulo do Lobo Terrane (PLT).

\section{$\underline{2.1 \text { Geological background }}$}

The OMZ includes an ancient core of Proterozoic age upon which different (volcano) sedimentary sequences were added, mostly during the Lower Paleozoic. Following the “Tectono-stratigraphic Terrane" perspective, two major stages of accretion were responsible for the present-day OMZ architecture (Quesada, 1991; Ribeiro et al., 2007). The first one, 
108 developed during Vendian (Upper Proterozoic) time, led to the formation of the Iberian

109 Terrane and was crucial for the crustal arrangement at the OMZ northern boundary. The 110 second stage, accomplished in the course of the Variscan Orogeny (but mainly throughout the 111 oblique continental collision that occurred in Upper Devonian to Carboniferous), led to the 112 juxtaposition of the OMZ with BAOC, PLT and SPZ terranes, playing a crucial role in the 113 configuration of the OMZ southern boundary.

\subsubsection{OMZ boundaries}

116 The exact position of the northern limit of the OMZ is a controversial issue despite the

117 abundance of data. For some authors it corresponds to the NW-SE igneous alignment known 118 as the "Los Pedroches Axis" (e.g., Lötze, 1945; Julivert et al., 1974) - Fig. 1b. For other

119 authors, it coincides with the Tomar-Badajoz-Córdoba shear belt (TBCS), even though with 120 distinct geodynamic meaning: a Variscan suture (Matte, 2001; Simancas et al., 2001) or a 121 Cadomian suture reworked in Upper Paleozoic times as an intra-plate sinistral flower 122 structure (Ribeiro et al., 1990; 2007 ; Quesada, 1991; Ribeiro, 2000). The recent re-evaluation 123 of stratigraphic and palaeogeographic data led San José et al. (2004) to the conclusion that 124 this boundary does not correspond to a simple lineament. Instead, it represents a narrow 125 WNW-ESE band (the Lusitan-Marianic Zone), with distinctive characteristics, bounded by a 126 pre-Variscan structure (subsequently sealed by the Los Pedroches batholith forming the "Los 127 Pedroches Axis") to the north, and the Alter do Chão - Malcocinado Fault Zone, to the south.

129 The OMZ southern limit has not been significantly modified since Lötze (1945), although the 130 actual significance of some geological units remains open to debate (Fig. 1b). Following the 131 most widely accepted interpretation, this boundary is the only rooted Variscan suture in Iberia 132 (Ribeiro, 1981; Munhá et al., 1989; Quesada et al., 1994; Díaz Aspiroz et al., 2004). In this 
context, the Exotic Terranes BAOC and PLT represent, respectively, an obducted (and

134 tectonically dismembered) ophiolite suite and an oceanic accretionary wedge developed from

135 Lower to Middle Devonian times (Araújo and Ribeiro, 1995; Fonseca et al., 1999; Ribeiro et

136 al., 2007). The current contact between PLT and OMZ or BAOC and PLT corresponds to the

137 Ferreira-Ficalho-Almonaster Thrust Zone, which is intersected and displaced by the ENE-

138 WSW, sub-vertical Ficalho-Aroche strike-slip fault. However, accumulated evidence strongly

139 suggests that the Ferreira-Ficalho-Almonaster Thrust Zone is merely a shallow expression of

140 a re-activated, deeper and more complex structure developed in the course of the OMZ-SPZ

141 late-collision stages (Mateus et al., 1999; Figueiras et al., 2002; Vieira da Silva et al., 2007).

\subsubsection{OMZ internal architecture}

The outcome of successive decades of multidisciplinary research supports the division of the

OMZ into distinct belts (domains), the most widely accepted being the one reported in Apalategui et al. (1990) based on tectonic criteria (structural style and deformation age). This

148 division consists of, from north to south, the Portalegre-Badajoz-Córdoba belt, the North-

149 Central Belt, the South-Central Belt, and the Southern Crystalline Complexes (Fig. 1b).

150 Despite several debatable issues concerning the lateral continuity and kinematics of some

151 tectonic structures, it can be shown that the limits of these belts (domains) coincide with

152 major thrust zones, roughly trending NW-SE and subjected to repeated re-activation in

153 Variscan times (Ribeiro, 1981; Quesada, 1991; Araújo, 1995). Accordingly, it is plausible to

154 admit that the geometry of these thrusts was strongly influenced by pre-existing fault zones,

155 delimiting intra-continental basins of variable extent and depth (Oliveira et al., 1991;

156 Quesada, 1991, Eguíluz et al., 2000, Silva and Pereira, 2004; Pereira et al., 2006a). Locally,

157 these tectonic contacts are displaced by late, strike-slip fault zones, especially those running 
158 between NNE-SSW and NE-SW, such as the Messejana Fault Zone, and those oriented

159 approximately ENE-WSW, such as the Ficalho-Aroche Fault. The Messejana Fault, an

160 outstanding deep structure that can be followed for approximately $530 \mathrm{~km}$, was initiated in

161 Late-Variscan times but successively re-activated during the Alpine Orogeny, as documented

162 both by multiple injections of dolerite rocks (Cebriá et al., 2003) and distinct displacements in

163 geological formations of different ages.

164

\subsubsection{Main lithostratigraphic features}

166 The oldest outcropping rocks in the OMZ (Fig. 2) are meta-sediments and meta-volcanics of

167 Neoproterozoic age, possibly deformed during Cadomian events and particularly well

168 exposed in the Portalegre-Badajoz-Córdoba and North-Central belts, although they can form

169 small windows in the southernmost OMZ domains (e.g. Eguíluz et al., 2000; Fernández-

170 Suárez et al., 2000; Simancas et al., 2004). The Upper Vendian to Lower Cambrian sequences

171 comprise felsic meta-volcanics and arkosic meta-sandstones, besides meta-conglomerate

172 levels, passing up into thick Lower Cambrian successions typical of carbonate platform; these

173 sequences are fairly well represented in the North-Central belt and in the SW compartment of

174 the Southern Crystalline Complexes Belt. Monotonous piles of pelites and meta-greywackes

175 with inter-bedded mafic volcanics represent the common sequences of Middle and Upper

176 Cambrian age that are particularly well exposed in the North-Central and South-Central belts.

177 The Lower Ordovician sequence is essentially made up of pelites passing up into Silurian

178 quartzites that are overlain by a condensed shale sequence of Silurian-Early Devonian(?) age,

179 that can be properly observed both in the North-Central and South-Central belts (Oliveira et

180 al., 1991; Robardet and Gutiérrez-Marco, 2004). In the SW compartment of the Southern

181 Crystalline Complexes Belt, the Cambrian-Ordovician-Silurian transitions are a subject of

182 controversy because of the strong tectonic dismembering and stacking, and because of 
difficulties in dating accurately some key formations. Nevertheless, according to recent data

184 (Araújo et al., 2005), the uppermost outcropping units in this belt are interpreted as tectonic mélanges. Meta-sedimentary sequences of Upper Devonian age, especially preserved in the South-Central belt, are thick and flyschoid in character, resting unconformably on older formations. Lower and Middle Carboniferous sequences, sometimes with coal beds, occupy

188 limited areas currently interpreted as intra-mountain basins (Eguíluz et al., 2000; Wagner, 2004; Pereira et al., 2006b).

All of these lithostratigraphic sequences were subjected to Variscan deformation and metamorphism, being also intruded by different igneous bodies. Strain accommodation took

193 place heterogeneously in the course of three main phases of deformation $\left(D_{1}\right.$ at $\approx 370-360$

$194 \mathrm{Ma}, \mathrm{D}_{2}$ at $\approx 340 \pm 20 \mathrm{Ma}$, and $\mathrm{D}_{3}$ at $310 \pm 10 \mathrm{Ma}$ ), generating a large variety of structures that 195 can be observed at all scales (e.g. Ribeiro et al., 2007; Quesada, 1991;Jesus et al., 2007). The early metamorphic event $(\approx 370 \mathrm{Ma})$ is represented by eclogite / blueschist rocks preserved in several $D_{1}$ nappes to be found in the Southern Crystalline Complexes Belt (Moita et al.,

198 2005a, b, c). The typical (regional) metamorphism recorded by the OMZ rocks progressed,

199 however, under greenschist to amphibolite facies conditions and occurred during $\mathrm{D}_{2}$ (Quesada 200 and Munhá, 1990; Castro et al., 1999; López-Munguira and Nieto García, 2004). The igneous 201 record is also multistage and compatible with these main geodynamic evolving stages; the 202 available data allow us to distinguish bodies that represent magmatism triggered by 203 subduction $(\approx 360 \mathrm{Ma})$ from those generated and emplaced during and after the OMZ-SPZ 204 oblique collision (from $\approx 355 \mathrm{Ma}$ to $\approx 300 \mathrm{Ma}$ ), the latter documenting the early to post205 collision igneous activity provided by different magmas (Castro et al., 1999; Pin et al., 1999; 206 Salman, 2004; Ribeiro et al., 2007). Despite these different granitoids, it is worth noting the 207 presence of Lower Paleozoic $(\approx 470-460 \mathrm{Ma})$ intrusions that show effects of Variscan 
deformation and outcrop both in the Portalegre-Badajoz-Córdoba and North-Central belts

209 (Simancas et al, 2004; Salman, 2004). Cenozoic (mainly clastic) sediments, forming 210 sequences of variable thickness related to the evolution of both major river systems and 211 restricted basins controlled by (still active) strike-slip fault zones, cover significant areas of 212 the OMZ Proterozoic-Paleozoic basement.

\section{$\underline{2.2 \text { Synopsis of previous electromagnetic imaging }}$}

215 From the geological features reported in the previous section, a moderate to high resistive

216 behavior for the shallow crustal levels of OMZ is expected with two main possible 217 exceptions. The first is the crustal domains, where the Upper Proterozoic sequences show 218 graphite-rich meta-sediments. The second corresponds to major fault zones that, regardless of 219 their geometry and kinematics, preserve sufficient quantities of interstitial aqueous fluids or 220 are sealed by mineral infillings that might result in adequate electrical contrasts in relation to 221 the host rocks. The results obtained from MT surveys carried out in SW Iberia (profiles S, P, $222 \mathrm{O}$ and L in Fig. 3) during the last decade confirmed this general prediction (Monteiro Santos 223 et al. 1999, 2002; Almeida et al. 2001, 2005; Pous et al. 2004; Muñoz et al. 2005). However, 224 they also provided evidence of other distinctive features, namely (i) the complex character at 225 depth of the OMZ boundaries, and (ii) the presence of middle-crust conductors locally 226 displaced by discrete sub-vertical bands or disrupted by resistive domains, interpreted as deep 227 tectonic structures or resistive igneous bodies, respectively. Nevertheless, the images reported 228 in those papers are insufficient to provide the desired regional view of the main geoelectrical 229 structures in the OMZ. Indeed, the lateral extension and geometry of these geoelectrical 230 structures, besides the spatial wideness of the detected conductive / resistive domains should 231 be addressed. The work of Vieira da Silva et al. (2007), presenting a 3D model for the 232 Portuguese part of the OMZ-SPZ boundary, shows that some debatable issues can be properly 
analyzed on this basis. The MT data currently available for the whole OMZ justifies the

234 development of a comprehensive 3D electromagnetic model, thus helping the characterization 235 of the OMZ deep crustal architecture and the OMZ boundaries at depth. Moreover, resolving 236 the real extension of middle-crust conductors in the $\mathrm{OMZ}$ highlights the role of crustal 237 heterogeneities in décollement tectonics related to the SW Iberian Variscides development, 238 which can be compared with those often involved in the growth of common orogenic belts.

\section{The new, integrative 3D model of the OMZ}

The MT data acquired along the six profiles displayed in Fig. 3 were analyzed or re-analyzed.

243 Previous publications discuss the data along the individual profiles: profile P (Monteiro 244 Santos et al. 1999, Almeida et al. 2001), profile O (Pous et al. 2004), profile S (Almeida et al. 245 2005), and profile L (Muñoz et al. 2005). The resistivity structures along all of these profiles 246 show a preferred strike direction between N100E - N125E and were interpreted assuming the 247 structure was two-dimensional. The new MT data presented in this paper consist of profiles I 248 and E. Profile I, located in the westernmost area of the OMZ, is a NNE trending $145 \mathrm{~km}$ long 249 profile consisting of 24 sites (Fig. 3) and the short profile E is located between profiles S and $250 \mathrm{P}$ with the same orientation and consists of 6 sites. Figure 4a shows six representative sites 251 from profile I (sites 21, 16, 3, 1, 10 and 12) and Figure 4b one site (6) from profile E (site 6). 252 As was the case for the previous profiles, the new data were acquired within the $0.004 \mathrm{~s}$ to $2534000 \mathrm{~s}$ period range. The measurement dipoles used to record the horizontal electric and 254 magnetic fields were oriented geomagnetic N-S and E-W. The vertical magnetic field 255 component was recorded at 15 sites on profile I and at 4 sites on profile E. Estimation of the 256 impedance tensor and transfer functions were carried out by using robust processing 257 techniques (Egbert and Booker, 1986). A dimensionality analysis of profile I was carried out 
258 by using the algorithm of McNeice and Jones (2001). This analysis showed a three259 dimensional character of the data. Indeed, no consistent 2D strike direction could be found for 260 a significant period range or group of sites, and the twist and shear curves show a frequency 261 dependency at all strike directions. Figure 5 shows the induction vectors at three periods. Note 262 that induction vectors (Parkinson convention) along profile I point to the West, indicating the 263 presence of a conductive body to the west of the profile. As we will show below the behavior 264 of the induction vectors cannot be explained by the effect of the ocean alone but also requires 265 a highly conductive body beneath the Tejo basin. The shape of the sounding curves also 266 suggests the presence of strong lateral conductivity changes adjacent to the profile. For 267 example the apparent resistivities in Fig. 4a, the XY mode (X - north; Y- east) is descending 268 at longer periods whereas the YX mode increases at these long periods. This feature of the 269 sounding curve is explained by a lateral conductor located east or west of the profile, and the 270 direction of the induction vectors indicates that this conductor is located to the west of the 271 profile. This behavior is inconsistent with a 2D structure; accordingly, 3D modeling is 272 required. The other profiles, even though they have a mainly $2 \mathrm{D}$ character, also show some 273 3D characteristics, i.e. the component of the induction arrows parallel to the strike (roughly E274 W) is not insignificant at some sites. The complete database (old and new sites) consist of 275 impedance tensors from 148 sites with periods ranging from $0.004 \mathrm{~s}$ to $4000 \mathrm{~s}$, and 276 geomagnetic transfer functions (tipper) recorded at 88 of these stations with the same period 277 range.

278 Three-dimensional forward modeling is by nature complex, particularly if a fine mesh is 279 required in order to resolve large conductivity contrasts in different regions. The OMZ is an 280 excellent case study for this type of modeling because of the large number of geoelectrical 281 structures evident from the previous 2D models and because of the proximity of the Atlantic 282 Ocean. 
The mesh (cell size and dimensions) was chosen as a compromise between structure

284 resolution and computational limitations. Accordingly, although it was refined in the areas 285 close to the shoreline to take into account the great resistivity contrast between land and sea 286 and in the areas where conductive anomalies appear, a coarser grid mesh was used and only 287 the relevant large regional structures are attempted to be imaged in the model.

The 3D forward algorithm of Mackie et al. (1993) with the modifications reported in Mackie and Booker (1999) was employed. The modeling code uses 2D extensions in the horizontal directions and a 1D extension beneath the base of the 3D model; it establishes a tangential magnetic field as a boundary condition.

\section{$\underline{3.1 \text { Ocean effect }}$}

The influence of the ocean on the MT data was evaluated by comparing the observed responses with those calculated using a simplified $3 \mathrm{D}$ model that incorporates the ocean $(0.3$ (.m) and a 1D resistivity model to represent crust and mantle (Fig. 6). Modeling was 298 performed taking into account the Iberian Peninsula shoreline and the approximate 299 bathymetry of the Atlantic Ocean. A mesh of 80 x 80 x 50 cells was used for the modeling. 300 Cell size within the Iberian Peninsula is about 5 to $10 \mathrm{~km}$, reducing to $\sim 2-4 \mathrm{~km}$ at the coast. 301 In the $\mathrm{z}$ direction cell sizes had to be much smaller to achieve convergence, $25 \mathrm{~m}$ for cells 302 closest to the surface. The 1D model of crust and mantle consists of three layers: a $100 \Omega \mathrm{m}$ $350 \mathrm{~m}$ thick layer, a $500 \Omega \mathrm{m} 35 \mathrm{~km}$ thick layer and a $5000 \Omega \mathrm{m} 420 \mathrm{~km}$ thick layer

304 representing the resistive mantle underlain by a $10 \Omega \mathrm{m}$ substratum (Fig. 6). The mantle 305 resistivity was chosen taking into account mantle resistivities obtained in similar contexts 306 (e.g. Constable and Constable, 2004; Monteiro Santos et al., 2003; Olsen 1998; Xu et al. 
2000) although the mantle resistivity was overestimated to emphasize the influence of the ocean mass on the MT data (high skin depth).

Figure 6 shows the induction vectors calculated using this simplified model of the SW Iberian Peninsula at periods of $20 \mathrm{~s}$ and $100 \mathrm{~s}$. Since the land model is $1 \mathrm{D}$, the induction vectors respond solely to the presence of the ocean mass. At a period of $20 \mathrm{~s}$ the oceanic influence is significant only at the southernmost sites. At a period of $100 \mathrm{~s}$ the effect caused by the ocean mass disturbs mainly sites placed along profiles I, S, and those positioned in the southern half of profiles $\mathrm{P}$ and $\mathrm{O}$. At longer periods the induction vectors at all sites respond to changes induced by the conductive water mass of the Atlantic Ocean (west and south of the studied 317 area).

Figure 7 compares the effect caused by the oceanic water mass on the apparent resistivity and

320 phase curves at sites nearest the coast for each profile with a site distant from the ocean. Also

321 shown are the responses of the $1 \mathrm{D}$ crust/mantle model. The differences in model response are 322 largest for profiles I and S. The influence on apparent resistivity values starts at about $10 \mathrm{~s}$, 323 and at about $5 \mathrm{~s}$ for phases. The difference is greater in the $\mathrm{XY}$ (X-north; $\mathrm{Y}$ east) polarization 324 for profiles I and S as the influence of the western oceanic water mass increases. For profiles $325 \mathrm{P}$ and $\mathrm{O}$ the difference is greater in the YX polarization (east-west current flow) because of 326 the southern position occupied by the oceanic water mass. The oceanic effect reduces as the 327 distance from the coast increases. At distances greater than $200 \mathrm{~km}$ (e.g. northernmost site of 328 profile $\mathrm{O})$ the effect of the ocean is negligible at our longest periods.

330 From this study one can conclude that the oceanic effect has two different components, one 331 coming from the water mass located to the west and the other resulting from the water mass 
332 located to the south. The western component affects mainly sites from profiles I and S at

333 periods longer than $100 \mathrm{~s}$, except for the southernmost sites where the influence starts at 5-10

334 s. At longer periods $(\mathrm{T} \approx 1000 \mathrm{~s})$ the western component affects the entire surveyed region.

335 The southern component affects the southernmost sites from profiles $\mathrm{O}$ and $\mathrm{P}$ at periods 336 longer than $10 \mathrm{~s}$.

338 The measured induction vectors at the shortest periods $(\mathrm{T}<10 \mathrm{~s})$ in profile $\mathrm{I}$ have greater 339 magnitudes than those calculated using the "ocean model" for the same periods;

340 consequently, the influence of the oceanic water alone cannot be invoked to explain this 341 behavior. This result was useful in the 3D model building of the OMZ, because it indicates

342 that a shallow conductor is required to the west of profile I. The long induction arrows 343 measured at the southernmost sites in profiles $\mathrm{P}$ and $\mathrm{O}$ can neither be explained by the 344 Atlantic Ocean influence alone, suggesting the presence of a shallow conductive anomaly to 345 the south of both profiles.

\section{$347 \quad 3.2$ Three-dimensional model of the OMZ}

348 A selection of the most representative sites for imaging the regional structure was made on 349 the basis of the morphology of their apparent resistivity and phase curves. Thus, all the 350 apparent resistivity curves were grouped into zones, each of which had curves of similar 351 morphology, which coincided with major geological units. From each group, one or more 352 sites were selected to complete the database for $3 \mathrm{D}$ modeling. Thus, the MT data used 353 consisted of the apparent resistivity and phase curves for 61 chosen sites and the geomagnetic 354 transfer functions (tipper) for 55 of these sites (the sites selected are marked in red in Fig. 3).

355 This site selection had the added benefit of reducing the effect of local galvanic distortion 356 (although not that at regional-scale, if present) on the data given that by choosing 
morphologies that are common to a group of sites a regional pattern weakly affected by local distortions should be achieved. The scattering in the levels of the apparent resistivities was not greater than one decade and the levels of the curves were shifted to an average level for each group, so that the apparent resistivity values at short periods were the same. These values generally are similar to the resistivity values obtained from $2 \mathrm{D}$ inversions from 362 previous data.

364 The starting model was built using the conductivity distribution obtained from the 2D models and the induction vector data (Fig. 5) as guides. The induction vectors help position conductive regions outside the area of data coverage, the vectors pointing to (Parkinson 367 convention) high conductivity regions. A mesh was built starting with a horizontal cell size of 368 about $5 \mathrm{~km}$ in the central part of the model. Tests were then carried out using finer meshes in 369 both horizontal and vertical directions until the calculated responses were asymptotically 370 stable. The greatest source of instability was found to be the vertical size of the cells. To 371 further assure the suitability of the discretization, a section across the 3D model was chosen 372 for 2D modeling. The corresponding 3D responses were then compared with the 2D responses 373 calculated with the code of Wannamaker et al. (1987) and using a similar mesh size for the 374 3D model (see e.g. Queralt et al. 2007). The agreement of the 2D and 3D responses gives 375 further confidence that discretization effects are negligible. The mesh used for the modeling 376 consists of $80(\mathrm{~N}-\mathrm{S}) \times 77(\mathrm{E}-\mathrm{W}) \times 76$ (vertical) cells. The average cell size employed was $4 \times$ $3774 \mathrm{~km}$ in the horizontal plane. In the vertical directions the cell size increases approximately 378 exponentially from $25 \mathrm{~m}$ in the first layers beneath the surface, $100 \mathrm{~m}$ at $1 \mathrm{~km}$ depth, $400 \mathrm{~m}$ at $3795 \mathrm{~km}$ depth, and so on to $50 \mathrm{~km}$ depth where the cell height reaches $5 \mathrm{~km}$. Below $45 \mathrm{~km}$, 380 where the deepest resistivity structures were located, several layers of uniform conductivity 381 were used in order to assure the uniformity of the electric field at the base of the 3D core of 
the model. The whole model occupies a volume of $737 \times 763 \times 85 \mathrm{~km}$, fully covering the $\mathrm{OMZ}$ and their boundaries.

After eighty-four 3D forward models, a feasible fit was obtained (Figs. 9, 10). The model sought to fit the apparent resistivity and phase curves of the off-diagonal components of the impedance tensor. In addition, the real and imaginary parts of both components of the geomagnetic transfer functions were fit. For the westernmost sites (profile I), the diagonal components of the MT impedance tensor were also fit. Figure 4 shows the data and model responses for some representative sites. The forward modeling provides a good insight into the resolution of the geoelectrical structures that possibly exist and allows us to identify those structures that are required by the data. During the modeling procedure the location, extent and resistivity value of the different structures were changed to assess the sensitivity of the model to the data. Special emphasis was placed on the structures of most significance for the geological interpretation.

Despite the complexity of the model and the difficulties in fitting diagonal components of the 398 impedance tensor, a reasonable fit was achieved. The RMS of the misfit for periods between $0.1 \mathrm{~s}$ and $3000 \mathrm{~s}$ and for each kind of data was calculated assuming an error floor of $10 \%$ for the apparent resistivities, $5^{\circ}$ for the phases and 0.05 for the magnetic transfer functions. The 401 global RMS is 5.42 for the apparent resistivities of the off-diagonal components, 2.79 for the 402 phases of the off-diagonal components, 14.96 for the apparent resistivities of the diagonal 403 components (profile I only) and 2.86 for the magnetic transfer functions. The overall RMS misfit for all the data is 4.58 The fit is distributed almost uniformly in the whole area as can 405 be seen for example in Fig. 8 where the absolute difference between observed and calculated 406 phases along the MT profiles are shown. In general, phase differences are less than $10^{\circ}$ for 
intermediate and lower frequencies (except profile $\mathrm{O}$ ); the misfit being greater for the highest

408 frequencies which no attempt was made to fit in detail.

410 The final three-dimensional model differs most from the starting model for the off-profile features.

411 The continuity of the different conductive and resistive structures was thoroughly tested to determine

412 the robustness of the features. For example, while conductor C3 (associated with the SPZ/OMZ

413 suture) must be continuous between the profiles $\mathrm{O}$ and $\mathrm{P}$, the conductor cannot be continued between

414 profiles $\mathrm{P}$ and $\mathrm{S}$ without producing a significant misfit with the data. In a similar way the interruptions

415 in conductors $\mathrm{C} 4, \mathrm{C} 5$ and $\mathrm{C} 8$ (associated with the OMZ/CIZ suture) and conductor C9 (the conductive

416 layer spanning the whole OMZ) were tested and found to be necessary in order to fit the data. These

417 features are compatible with the resistivity distribution found in the $2 \mathrm{D}$ inversions of the different

418 profiles. Figure 11 compares the responses of the final model (Figs. 9, 10) with some of the test

419 models. In the first test (Fig. 11a) the resistive interruption of conductor C3 (associated with the

420 SPZ/OMZ suture) and the southernmost part of profile $\mathrm{S}$ was removed. As can be seen in the

421 responses of the southernmost sites of profile S (e.g. site S9 in the figure) the minima in the apparent

422 resistivities become much deeper and thus do not fit the data. A second test (Figs. 11b and 11c)

423 consisted in replacing the complex conductive structure formed by conductors $\mathrm{C} 4, \mathrm{C} 5, \mathrm{C} 8$ (associated

424 with the OMZ/CIZ suture) and C9 (the conductive layer spanning the whole OMZ) by a simple layer

425 with a resistivity of $20 \Omega \mathrm{m}$ from a depth of $10 \mathrm{~km}$ down to a depth of $30 \mathrm{~km}$. In this case the complex

426 structure is necessary to explain the splitting of the apparent resistivity curves (e.g. at sites P34 and

427 O24 in the figure). In addition, the removal of the resistivity interruptions in these conductors yields

428 deeper minima and thus increased misfit with the data. In another test (Fig. 11d) the localized

429 conductor C6 was replaced by a more extended, less conductive feature. As shown in the figure, the

430 misfit becomes much larger, the splitting of the apparent resistivities being due to the proximity of site

431 E6 to the edge of conductor C6. By contrast, in the sensitivity test, this edge is located at some 432 distance from site E6. 


\section{$\underline{3.3 \text { Resistivity distribution }}$}

The 3D resistivity model results for the OMZ show 9 distinct areas with high to moderate conductivity (C1 to C9) and three highly resistive areas (R1, R2 and R3) (Figs. 9, 10).

At the surface, the most noteworthy feature corresponds to a moderately conductive domain (C1) that is NE-SW elongated and shows an "L" shaped tail to the southeast; its presence is essentially indicated by the western component of the induction arrows of profile I and the particular shape of apparent resistivities and phases (see Fig. 4a). Down to $10 \mathrm{~km}$ depth, C1 forms a well defined NNE-SSW conductive band $\approx 200 \mathrm{~km}$ long and $50-75 \mathrm{~km}$ wide, with a resistivity of $20 \Omega \mathrm{m}$. The band becomes more conductive $(10 \Omega \mathrm{m})$ at deeper levels, but is less distinct below $15 \mathrm{~km}$ depth. In the north, $\mathrm{C} 1$ completely disappears below $20 \mathrm{~km}$ depth; its southern portion, however, can be followed to a depth of $30 \mathrm{~km}$.

The conductive domain $\mathrm{C} 2$ is required to explain the induction vectors of the southernmost sites in profiles $\mathrm{P}$ and $\mathrm{O}$. It can be followed down to $20 \mathrm{~km}$ depth, suggesting a progressive rotation from NE-SW to E-W and showing a gradual conductivity decrease with depth (1-5 $\Omega \mathrm{m}$ in the first $3 \mathrm{~km}$ and $10 \Omega \mathrm{m}$ in the next $17 \mathrm{~km})$.

$\mathrm{C} 3$ is a well-defined conductor $(5 \Omega \mathrm{m})$ that is resolved from 5 to $30 \mathrm{~km}$ depth and, in its maximum extent, runs for more than $180 \mathrm{~km}$ along the E-W direction, therefore representing the most important geoelectrical structure in the southern part of the surveyed area. The eastern segment of $\mathrm{C} 3$ is clearly defined at $5 \mathrm{~km}$ depth and dips to the west, showing a bent geometry that persists down to a depth of $30 \mathrm{~km}$. The complete extension of $\mathrm{C} 3$ is only achieved after $15-20 \mathrm{~km}$ depth, when its western segment is clearly evident without any ambiguity. 
$\mathrm{C} 4, \mathrm{C} 5, \mathrm{C} 6$ and $\mathrm{C} 7$ are clearly identified from $5 \mathrm{~km}$ depth downwards. These domains in the northern part of the surveyed area show similar directions (varying from WNW-ESE to NW$\mathrm{SE})$ and resistivity values ( 1 to $10 \Omega \mathrm{m}$ ); their extent ranging between 50 and $200 \mathrm{~km}$. From 10 to $15 \mathrm{~km}$ depth all these domains, including $\mathrm{C} 8$, enlarge and band together, merging into a wide middle-crust conductive layer, C9, which reaches a depth of $30 \mathrm{~km}$ (Fig. 9).

The image obtained also shows several high to very-high resistive domains (more than 2000 $\Omega \mathrm{m}) . \mathrm{R} 1$ and R2 are the largest and most significant crustal resistive domains that represent typical features of the northern part of the surveyed area. R1 extends from 5 to $45 \mathrm{~km}$ depth and shows a kink geometry, between the conductors $\mathrm{C} 5$ and $\mathrm{C} 7 / \mathrm{C} 8$ and limited to the east by $\mathrm{C} 4$; its resistivity is $5000 \Omega \mathrm{m}$ or greater. The R2 domain, also present at all depths, in the NW corner of the surveyed area is notably enlarged when $\mathrm{C} 1$ is reduced to its southern portion (below $20 \mathrm{~km}$ depth); its resistivity is at least $2000 \Omega \mathrm{m}$. The R3 domain can be followed down to a depth of $20 \mathrm{~km}$ and shows a consistent positioning right from the surface level, sitting between $\mathrm{C} 2$ and $\mathrm{C} 3$.

Despite the coarseness of the grid used in this large model and the wide spatial sampling, the resulting model is consistent with that obtained in earlier 2D and 3D models (Monteiro Santos et al. 1999; Almeida et al. 2001, 2005; Pous et al. 2004; Muñoz et al. 2005; Vieira da Silva et al., 2007). The presence of these conductors was well established in the previous $2 \mathrm{D}$ models. Namely, C7 and C4 in profile L (Muñoz et al., 2005), C5, C6, C7 and C3 in profile O (Pous et al 2004), C2, C3, C6, C8 and C5 in profile P (Almeida et al. 2001) and C6 in profile S (Almeida et al., 2005). The contribution of our 3D modeling is the delineation of the resistivity structure for the new profile I and the confirmation of the lateral continuity of the main structures across the OMZ identified by previous 2D modeling. The merging of the 
main conductive anomalies in OMZ led to the image of one conductive layer spanning the whole $\mathrm{OMZ}$ and extending into the CIZ. This allows us to correlate the MT data acquired in different sampling profiles and, consequently, to visualize the resistivity pattern of the OMZ.

\section{Geological interpretation}

A reasonable geological interpretation of the resistivity patterns obtained should consider the resistivity contrasts produced by the spatial arrangement of diverse rock types that may contact each other tectonically. Given the spatial sampling (site and profiles distance) and the cells dimension used, only the geoelectrical structures with regional influence can be identified, sometimes integrating the response of close-spaced geological formations or subparallel, although distinct, tectonic structures. Accordingly, the conductive and resistive domains provided by the reported 3D model should reflect the main geological features at depth, thereby helping to solve pending issues regarding the nature and structure of the crust of the $\mathrm{OMZ}$ and along its western, southern and northern boundaries.

The geological significance of $\mathrm{C} 1$ is uncertain. At shallow depths $\mathrm{C} 1$ coincides with a part of the western Cenozoic sedimentary basin. However, the maximum thickness of the Cenozoic sedimentary sequence is $\approx 600 \mathrm{~m}$ and occurs in narrow NE-SW trending grabens, according to gravimetry, geoelectrical surveys and several drill-holes (Oliveira et al., 2001). Therefore, a more realistic interpretation is needed because $\mathrm{C} 1$ extends down to a depth of $30 \mathrm{~km}$, preserving the NNE-SSW direction despite the strong disruption at about $15 \mathrm{~km}$ depth and the gradual vanishing of its northern portion. Considering these features together with the available geological data, it seems that, in the upper $10 \mathrm{~km}, \mathrm{C} 1$ could represent the bulk resistivity of PLT and SPZ upper crust located to the west of the NNW-SSE thrust fault zone that currently makes up the OMZ western limit. Consequently, this tectonic boundary does 
not have any intrinsic feature that enables its resolution. Moreover, the conductivity increase

in $\mathrm{C} 1$ from $\approx 15 \mathrm{~km}$ depth downwards may be taken as evidence for the presence of a

511 different crustal layer at that depth. In this interpretative scenario C1 correlates with $\mathrm{C} 2$, their

512 horizontal (and vertical?) separation being accomplished by an early NE-SW tectonic

513 structure, subsequently re-activated by the Messejana fault zone in Late-Variscan times, as

514 already reported by the work of Vieira da Silva et al. (2007) in the same area. Note also that

515 the disruption of $\mathrm{C} 1$ at $\approx 15 \mathrm{~km}$ depth strongly suggests the presence of a sub-parallel tectonic

516 structure to the north of the Messejana alignment. Nevertheless, this interpretation implies the

517 need for a suitable explanation for both the moderate resistive behavior of these tectonic 518 structures and for the $\mathrm{C} 2$ conductivity change with depth.

520 The weak resistivity contrast shown by the NE-SW deep tectonic structures could be

521 explained by either or both the poor model resolution and the presence of the igneous roots of

522 the outcropping dolerites. Variations in C2 conductivity are more complex and are believed to

523 reflect different causes. The high conductivity of the uppermost part of C2 shows mainly the

524 abundant massive sulphide bodies within the outcropping volcano-sedimentary successions

525 that characterize the Iberian Pyrite Belt in SPZ, in addition to the presence of graphite-rich

526 schists locally over-thickened as a result of the thin-skinned tectonic regime during Variscan

527 times (e.g. Ribeiro and Silva, 1983; Oliveira, 1990; Quesada, 1998; Oliveira et al., 2004).

528 From 5 to $\approx 15 \mathrm{~km}$ depth, the $\mathrm{C} 2$ spatial positioning and orientation strongly suggest that it

529 corresponds to the remaining Upper Paleozoic sequences in SPZ. The higher conductivity of

$530 \mathrm{C} 2$ compared to $\mathrm{C} 1$ at this depth range is interpreted as the strengthening of the bulk effect

531 associated with the tectonically imbricate Upper Paleozoic complex (down to 8-9 km) and its

532 contact with the Lower Paleozoic successions through a major décollement already evidenced

533 by deep seismic profiles (Prodehl et al., 1975). From 15 to $20 \mathrm{~km}$, the conductivity of C2 and 
$534 \mathrm{C} 1$ is similar, representing the autochthonous Lower Paleozoic layer, in good agreement with

535 the seismic data (Prodehl et al., 1975). As a result, the $20-30 \mathrm{~km}$ depth layer should mostly

536 correspond to the SPZ lower crust (granulitic basement?), which is also consistent with the

537 available seismic data (Prodehl et al., 1975). The R2-C1 (C2) electrical resistivity contrast

538 suggests that the disruption of $\mathrm{C} 1$ at $\approx 15 \mathrm{~km}$ depth caused a significant rising of the $\mathrm{C} 1$

539 northern portion, thus allowing the spatial coexistence of different levels of the SPZ

540 basement, the lower ones having a tendency to be more resistive.

542 The foremost geoelectrical structure identified by the 3D model is determined by the

543 enlargement and coalescence of different upper to middle-crust conductive domains in OMZ,

544 quite obvious at $\approx 15-20 \mathrm{~km}$ depth, but continuing down to $\approx 30 \mathrm{~km}$ (C9, Fig. 9). At a depth

545 of $20 \mathrm{~km}$ this sub-horizontal structure covers more than $200 \mathrm{~km}$ in E-W direction and almost

$546185 \mathrm{~km}$ in a N-S direction, merging the internal conductive domains with those related with

547 the $\mathrm{OMZ}$ boundaries (such as $\mathrm{C} 3$ and $\mathrm{C} 8$ - see below). It thus represents a middle-lower

548 crustal level that, in the first $5 \mathrm{~km}$ (roughly from 15 to $20 \mathrm{~km}$ depth), behaves as a sole

549 conductive layer locally interrupted by plutonic intrusions (like R1) and/or displaced by deep,

550 sub-vertical tectonic structures (such as C6). The electromagnetic imaging obtained is

551 compatible with a granulitic basement that extends as far as the Moho transition $(\approx 30-35 \mathrm{~km}$

552 depth, also pointed out by Simancas et al., 2003, using seismic data) and is thought to

553 comprise a variable fraction of interconnected grain-boundary films of graphite (Monteiro

554 Santos et al., 2002). The conductivity is higher at the top of this layer and that feature can

555 result from a more effective connectivity of graphite at this level $(15-20 \mathrm{~km})$. This is

556 emphasized when results of a recent seismic profile are considered (Simancas et al., 2003;

557 Carbonell et al., 2004), showing that a straight spatial correspondence exists between the

558 conductive layer and a $2 \mathrm{~s}$ thick reflective band, known as Iberian Reflective Body (IRB). 
560 The most promulgated interpretation of IRB considers this huge band as a large layered

561 igneous sill, presumably the source of Lower Carboniferous magmas (Simancas et al., 2003;

562 Carbonell et al. 2004; Tornos and Chiaradia, 2004; Tornos and Casquet, 2005; Tornos et al., 563 2005). However, as noted by Pous et al. (2004), the presence of this igneous sill should 564 produce a resistive rather than conductive behavior, unless a multiple sheet-like intrusion 565 separated by screens of graphite-bearing metamorphic rocks is considered. For this reason, a 566 significant part of the $\approx 15-20 \mathrm{~km}$ depth layer was interpreted as the base of a Proterozoic 567 meta-sedimentary pile (Pous et al., 2004); even so, only a fortuitous convergence of causes 568 might justify the presence of a deep metamorphic level consistently enriched in graphite and 569 almost uniformly distributed all over the OMZ. Further considerations regarding either the 570 constraints imposed to multiphase magma emplacement in a (very) special rheological crust 571 level or the thermal regimes suitable for a long-lived and widespread magma feeding led 572 Vieira da Silva et al. (2007) to favor the alternative interpretation already drawn in Monteiro 573 Santos et al. (2002) and Almeida et al. (2005). The conductive and reflective layer IRB should 574 represent not an igneous sill but a very important middle-crust décollement, largely developed 575 immediately above or coinciding with the top of the $\mathrm{OMZ}$ granulitic basement. A very recent

576 review concerning the abundance and timing of the early to post-collisional Variscan 577 magmatism in OMZ also supports this alternative interpretation (Jesus et al., 2007). 578 Therefore, the development of a wide conductive layer in OMZ at a depth of $\approx 15-20 \mathrm{~km}$ 579 could be caused by a reinforcement of the conductive behavior resulting from the formation 580 of graphite fine-aggregates along movement planes related to this major décollement. 581 Additionally, domains of the décollement that are intersected by very deep sub-vertical 582 tectonic structures or act as "merging points" of fault zones recognized at shallower crustal 583 levels are potential sites for the development of massive graphite aggregates provided that C- 
rich fluids were generated and their circulation sufficiently effective. In these circumstances,

585 some sort of electrical anisotropy can be developed nearby or within the conductive layer, tending to form a sequence of blobs of higher conductivity (Heise and Pous, 2001, 2003).

As stated above, limits of the OMZ internal belts coincide with major thrust zones, consistently trending NW-SE and often subjected to several re-activation events. Some of 590 these tectonic structures are resolved in the 3D electromagnetic imaging now obtained despite 591 the general moderate to high resistive character in the first $5 \mathrm{~km}$ depth (see below). Of these, 592 the boundaries between belts that constitute the northern part of the OMZ stand out, as shown 593 in Fig. 1b. It is worth noting that the deep conductor C6 roughly divides the OMZ into two 594 blocks, of distinct electrical behavior, with depths down to $10 \mathrm{~km}$. Another prominent feature 595 concerns the fact that all these tectonic structures show a distinctive conductive character 596 from 8 to $\approx 20 \mathrm{~km}$ depth, reaching a maximum contrast (and differentiation, although 597 preserving their trend) at a depth of $15 \mathrm{~km}$, the top of the middle-crust décollement.

599 The difficulty of resolving the tectonic limits between the OMZ internal belts along the initial $6008 \mathrm{~km}$ depth is interpreted as a consequence of the abundant igneous bodies currently existing 601 at shallow crustal levels regardless of the problems caused by the coarse mesh used in the 602 model construction. That is why the average electrical structure is moderately to highly 603 resistive (500-2000 $\Omega \mathrm{m}$ ), allowing in spite of this the delimitation of highly resistive zones $604(5000 \Omega \mathrm{m})$. The shallowest are easily correlated with the roots of prominent outcropping 605 granitoid batholiths or gabbro-diorite complexes that developed during the Variscan orogeny 606 (e.g. Carretero et al., 1990; Pin et al., 1999; Salman, 2004; Jesus et al., 2007). Note, however, 607 that from $8 \mathrm{~km}$ downwards, only two main resistive domains persist. The first one, labeled $608 \mathrm{R} 1$, extends down to $45 \mathrm{~km}$ depth and may reflect the crustal distribution of different igneous 
rocks related to the deep magmatic activity that developed continuously in Paleozoic times

610 roughly along the OMZ and CIZ boundary. The second one (R3) cannot be traced below 20

$611 \mathrm{~km}$ depth, but shows a consistent positioning right from the surface level, sitting between $\mathrm{C} 2$

612 and C3; it should also represent variable outputs of the Variscan magmatic activity, roughly

613 located along the PLT and SPZ boundary.

614

615 The electromagnetic imaging obtained does not shed much light on the debate on the real 616 position of the OMZ-CIZ boundary. It simply reveals that there is a very good 617 correspondence between the trace of the major, graphite bearing, tectonic structures that 618 organize the crust in this complex belt and a group of sub-parallel deep conductors (C8-C7, 619 C4 and C5), which show a tendency to merge in the western domain at a depth of $\approx 20 \mathrm{~km}$ 620 (Fig. 9). However, an alternative interpretation may be considered. In fact, the relative 621 positioning of these conductors at different depths strongly suggests that C8 is sub-vertical. 622 Accordingly, C8 is the only geoelectrical structure that may represent the OMZ-CIZ 623 boundary, clearly defined down to $27 \mathrm{~km}$ depth and reflecting the bulk signal of TBCS, which 624 includes different sub-parallel thrust zones. This NW-SE conductor extends for more than 220 $625 \mathrm{~km}$ and, in the easternmost domain of the surveyed area, merges with $\mathrm{C} 7$ (a shallower 626 conductive anomaly whose top is evidenced at a depth of $6 \mathrm{~km}$ ), reflecting suitably the 627 geometric pattern of the main outcropping tectonic structures (Fig. 1b). From this perspective, $628 \mathrm{C} 4$ and $\mathrm{C} 5$ are envisaged as important features of the CIZ southern border, perhaps tracing the 629 development of thrust systems that start to merge at $10 \mathrm{~km}$ depth. The gradual coalescence of $630 \mathrm{C} 4$ and $\mathrm{C} 5$ form a middle-crust conductive layer that joins the one recognized in the OMZ and 631 extending into CIZ. At greater depths, however, C4 and C5 are still detected, thereby 632 suggesting that their electrical properties are due to causes similar to those aforementioned for 633 OMZ. The merit of this alternative interpretation resides in its good agreement with the 
634 seismic data reported in Simancas et al (2003) and Carbonell et al. (2004), which indicated

635 the continuity of the IRB into the CIZ.

636

637 The $\mathrm{OMZ}$ southern boundary roughly coincides with $\mathrm{C} 3$, an elongated geoelectrical structure 638 that strikes approximately E-W and can be followed for more than $180 \mathrm{~km}$. The whole 639 extension of C3 can only be appreciated from 15 to $30 \mathrm{~km}$ depth, despite a small break in its 640 westernmost portion caused by the early NE-SW tectonic structure related to the C1-C2 641 separation. In the top $5 \mathrm{~km}, \mathrm{C} 3$ is not detected; instead, a transition between two resistive 642 domains comes into view, reflecting a slight contrast in the bulk electrical conductivity 643 between geological formations belonging to the OMZ southern border and to PLT-BAOC644 SPZ. The first conclusive evidence of C3 emerges at a depth of $5 \mathrm{~km}$, revealing a bent 645 structure that is confined to the easternmost segment of the geological contact, perhaps 646 integrating the influence of different tectonic structures, such as early thrust zones along the Variscan suture affected by the ENE-WSW, sub-vertical Ficalho-Aroche strike-slip fault (Fig. 1b). The top of the remaining portion of $\mathrm{C} 3$ becomes visible only at $15 \mathrm{~km}$ depth; this is 649 consistent with the results reported in Vieira da Silva et al. (2007) that allowed settling the 650 roots of BAOC (made up of resistive rocks) from $12 \mathrm{~km}$ depth onwards. Accordingly, the westernmost portion of $\mathrm{C} 3$ shows a weak contrast with $\mathrm{C} 2$ between 15 and $20 \mathrm{~km}$ depth, given their spatial proximity and the local tectonic disturbance, which becomes clearly resolved at deepest levels $(>22 \mathrm{~km})$ where it should really trace the Variscan suture. This 654 interpretative background is consistent with other geological evidence that strongly supports 655 either the late character of the Ferreira-Ficalho-Almonaster Thrust Zone (Mateus et al., 1999; 656 Figueiras et al., 2002), or significant differences in the suture geometry reflecting primary 657 dissimilarities on the OMZ-SPZ tectonic boundary (e.g. Quesada et al., 1994; Fonseca, 1995; 658 Fonseca et al., 1999; Díaz Aspiróz et al., 2004; Jesus et al., 2007; Ribeiro et al., 2007). 


\section{Implications for décollement tectonics}

662 The new 3D electromagnetic image obtained for OMZ and its boundaries provide evidence of 663 an extensive middle to lower crustal conductive layer ( $\approx 15$ to $30-35 \mathrm{~km}$ depth), its top $(\approx 15-$ $66420 \mathrm{~km}$ depth) being of higher conductivity, already corroborated by previous studies 665 (Monteiro Santos et al. 2002; Almeida et al. 2001, 2005; Pous et al. 2004; Muñoz et al. 2005). 666 This top is interpreted as a major décollement between the granulitic basement and the 667 overlying meta-sedimentary pile. The geotectonic units sited to the north and south of OMZ 668 (CIZ and SPZ, respectively) seem to develop an identical sub-horizontal structure at similar depth, although poorly resolved given the extent of the MT profiles and parameterization used in model building. The same deduction was reported in earlier works that exploited just part

671 of the MT data used in this study (Monteiro Santos et al., 1999; Muñoz et al., 2005; Vieira da 672 Silva et al, 2007). At the OMZ-CIZ boundary (e.g. Ribeiro, 1981, 2000; Quesada, 1991; 673 Ribeiro et al., 1990, 2007; Simancas et al., 2001, 2004) the two middle-crust décollements merge, even though the trace of the main geoelectrical structures can be followed from $20 \mathrm{~km}$ depth onwards as far as the Moho transition (at a depth of 30-35 km). A somewhat distinct

676 framework develops at the OMZ-SPZ boundary (e.g. Munhá et al., 1989; Quesada et al., 677 1994; Araújo, 1995; Fonseca, 1995; Fonseca et al., 1999; Diaz Aspiroz et al., 2004). This is, 678 in part, due to significant (and possibly primary) differences between the eastern and western 679 segments of the tectonic boundary, currently separated by a Late-Variscan, ENE-WSW strike680 slip fault. However, the influence caused by the tectonically complex belt that includes the 681 Exotic Terranes PLT and BAOC cannot be ignored, particularly along the first $10-15 \mathrm{~km}$ 682 depth. The whole extension of the SW Iberian Variscan suture is resolved without ambiguity 683 from $22 \mathrm{~km}$ to $30 \mathrm{~km}$ depth, where the transition to the Moho should occur. From this brief 
statement, it seems that décollement tectonics played a crucial role in stress and strain

685 partition within the lithosphere during the SW Iberian Variscides development, agreeing with geological inferences as discussed by, e.g., Matte (1986, 2001), Franke (2000) and Ribeiro et al. (2007). Accepting this interpretation, which is in good agreement with the available seismic reflection data (Simancas et al., 2003; Carbonell et al., 2004), two main questions 689 may be posed: (1) what kind of crustal heterogeneities were mainly involved in the 690 décollement tectonics and how were they generated?; (2) what were the major rheological and 691 thermal constraints involved in the SW Iberian Variscides development? Answering these 692 questions not only helps to understand better this Paleozoic Orogen, but also raises some 693 questions about the issues concerning the growth of common orogenic belts.

695 The common rheological stratification shown by the continental lithosphere reflects its 696 strength variation with depth (recording mostly changes on mineral composition, fluid 697 abundance and temperature), even though the rate, duration and style of the accommodated 698 deformation ultimately depend on the uppermost mantle layer strength (England and 699 Mckenzie, 1982; Houseman and England, 1986; Ranalli and Murphy, 1987; Grocott et al., 700 2004). These interdependent relationships strongly influence the pattern of vertical (stress 701 and) strain partitioning during the orogenesis in which the shallow and more deformed crustal 702 level is decoupled from the lower crust, which in turn is decoupled from the uppermost 703 mantle, by décollement systems (e.g. Cook, 1984; Oldow et al., 1990; Tikoff et al., 2004). 704 Therefore, taking into account the geodynamic evolution experienced by the OMZ (e.g. 705 Ribeiro et al., 2007) and the results of different numerical modeling (Harry et al., 1995; 706 Teyssier and Cruz, 2004), sub-horizontal shear zones (acting as décollements and transmitting 707 the shear stress) are expected to develop in the lower and middle crust as a natural 708 consequence of contraction in a rheologically stratified lithosphere (Beaumont and Quilan, 
1994; Harry et al., 1995). However, given the discrepancy between the geodynamic evolution experienced by the northern and southern OMZ boundaries, some particular features must be considered.

Assuming that the OMZ northern boundary represents a Cadomian suture re-activated during Variscan orogeny (e.g. Ribeiro, 1981; Matte, 1986, 2001; Ribeiro et al., 1990, 2007) implies the recognition of the pre-existence of an important crustal weakness, which determines strain partitioning in this crustal domain. In these circumstances, the development of a décollement at the base of the weak meta-sedimentary pile is favored, promoting vertical strain decoupling instead of pure shear thickening of the upper crust. Thus, in the underlying crystalline crust the magnitude of maximum strain decreases downward as strain becomes distributed over a wider area (Harry et al., 1995; Teysser and Cruz, 2004). Consequently, at all depths high strain accumulation will be restricted to the width of the region surrounding the weakened portion of the lithosphere, with the locus of highest strain resting near the TBCS inner belt. This will favor the development of sub-parallel thrust zones that tend to merge in a sole décollement, as observed, separating the tectonically disrupted upper crust from the relatively un-deformed crystalline basement. Further evolution will therefore be strongly influenced by the generated mechanical heterogeneities at middle crustal or shallower depths.

The development of the $\mathrm{OMZ}$ overall conductive and reflective middle-crust layers should be

729 related to the mechanical heterogeneities generated during the OMZ-SPZ continental 730 collision, namely throughout the formation of a kinematically coupled system that 731 incorporates a pro-wedge (the Iberian Pyrite Belt in SPZ), an axial zone (PLT) and a retro732 wedge (the OMZ southernmost belt) domain (Jesus et al., 2007). Indeed, the presence of an 733 important foreland basin in the SW Iberian Variscides strongly suggests that crustal 
734 thickening during orogenic shortening impeded the creation of a large crustal root, and excess buoyancy within the lithosphere resulting in a very limited uplift of the shallow crust, as corroborated by numerical models (Harry et al., 1995). This statement is also compatible with the fact that basal foreland thrusts are not rooted beneath the hinterland, and that (thinskinned) deformation in the foreland is restricted to the upper 10 to $15 \mathrm{~km}$ of the crust, as deduced from the available seismic reflection profiles. Accordingly, the foreland shortening could not be accommodated within the OMZ hinterland by homogeneous contraction, favoring crust decoupling from the underlying mantle and re-enforcing the thermal weakness character of the $\mathrm{OMZ}$ southern border (acting as a retro-wedge system); this mechanical behavior was further assisted by significant magmatism as a result of the local incursion of the asthenospheric mantle allowed by the inferred slab break-off (Jesus et al., 2007).

Following the results of numerical and analogue models (e.g. Harry et al., 1995; Tikoff et al., 2004; Willingshofer et al., 2005), the crust-upper mantle decoupling in OMZ during the early collision stages should be represented by a décollement deforming at a high rate of high strain, which could extend beneath the entire width of the hinterland, causing contraction and local thickening of the lower crustal level. Concurrently, pure shear shortening and crustal thickening is expected to progress in the upper crust of the OMZ southern border. The outstanding geological record of the structures that reflect this strain accommodation is consistent with the development of a second décollement at the base of the weak metasedimentary pile in the middle crust, partially decoupling strain in the lower crust from strain within the upper crust.

As collision proceeds, deformation at middle-crust and shallower depths on the OMZ southern border would be more concentrated where the middle-crust décollement is straining 
most quickly. Therefore, deformation in the upper crust of the OMZ southern border should be driven by shear along the middle-crust décollement, which is expected to be less rapid and more broadly distributed than on the BAOC, PLT and SPZ northern boundary. In subsequent geodynamic stages, the middle-crust décollement should have been able to widen, expanding toward the OMZ interior and allowing the propagation of deformation in the upper crust toward the hinterland. Consequently, the thrust systems observed in $\mathrm{OMZ}$ only penetrate to middle-crust levels, leaving the lower crust un-faulted, thereby supporting the interpretation for the IRB and the top of the conductive layer. This general inference is also compatible with the available geological data that enable us to deduce several hundreds of kilometers of shortening over a period of 90-100 Ma, providing additional evidence of multiple orogenic episodes over periods of several tens of Ma (e.g. Ribeiro et al., 2007).

The conformity existing between MT and seismic surveys for OMZ and SPZ, as well as their agreement with geological interpretations based on detailed mapping and multidisciplinary research, strongly suggests that major décollements developed at middle and lower-crustal depths play a crucial role in orogen growth. These décollements extend throughout the entire width of the orogen and provide a successively increasing degree of decoupling between deformation in the shallow crust and deeper levels. This significant strain partitioning within the lithosphere, is believed to be a common feature of orogens involving oblique continental collision (Sanderson and Marchini, 1984; Oldow et al., 1990, Teyssier et al., 2002; Grocott et al., 2004).

\section{Conclusions}

Earlier MT surveys on OMZ have elucidated a number of resistive and conductive features that are related to major structural features and play a significant role in the architecture of 
784 this terrane. The 3D electromagnetic imaging now obtained, covering entirely the $\mathrm{OMZ}$ and

785 its boundaries, corroborates earlier results and, for the first time, provides a complete picture

786 of the geometry and wholesale spatial distribution of the detected resistivity pattern. A brief

787 synthesis of the features resolved is given below:

(1) PLT and SPZ geological formations in contact with OMZ are more conductive than those belonging to the $\mathrm{OMZ}$ terrane along the upper $10 \mathrm{~km}$ depth.

(2) The NNW-SSE thrust fault zone that currently makes up the OMZ western limit has no intrinsic feature that enables its electrical resistivity resolution.

(3) The décollement inferred from seismic data for SPZ, splitting the upper thin-skinned complex from the Lower Paleozoic cover at $\approx 8-9 \mathrm{~km}$ depth, is not accurately resolved

(4) The OMZ southern boundary roughly coincides with an elongated geoelectrical structure that strikes approximately E-W and can be followed for more than $180 \mathrm{~km}$. The Variscan suture can only be completely resolved from $\approx 22 \mathrm{~km}$ depth onwards

(5) Some of the tectonic structures that bound the OMZ internal belts are resolved despite given the poor electrical resistivity contrasts obtained for upper crustal levels and the

(6) The widespread conductive character of the $\mathrm{OMZ}$ crustal layer from $\approx 15$ to $30-35 \mathrm{~km}$ depth is interpreted as a result of graphite distribution in the granulitic basement. The 
higher conductivity of the upper part of this layer $(\approx 15-20 \mathrm{~km}$ depth $)$ should reflect mostly an important middle-crust décollement enriched in fluid-deposited graphite as a consequence of Variscan shearing.

(7) There is spatial correspondence between the major $\mathrm{OMZ}$ middle-crust décollement and the $2 \mathrm{~s}$ thick reflective band, known as the Iberian Reflective Body (IRB Simancas et al., 2003; Carbonell et al., 2004).

(8) The main outcropping, sub-parallel thrust zones that form the OMZ-CIZ boundary, are

Mechanical heterogeneities that may have influenced the deformation style in the SW Iberian Variscides result mainly from the geodynamic evolution experienced by the OMZ-SPZ tectonic boundary. Strain partitioning into shallow (thin-skinned) deformation in the foreland 826 (SPZ) and deep-seated deformation in the hinterland (OMZ) was primarily accommodated by 827 the development of décollement systems in the middle and lower crusts which extend beneath 828 the entire width of the orogen. The lateral growth of these décollement systems during 829 shortening results both in the SPZ leading edge migration toward OMZ and in the gradual 830 propagation of deformation to deeper crustal levels of the proximal foreland. Strain 831 partitioning into deep-seated deformation in OMZ and shallow deformation in SPZ, and the 832 progressive growth of deformation both outward and downward with time, are compatible 833 with geodynamic models proposed for the SW Iberian Variscides that regard the OMZ 
834 southern boundary as the only rooted Variscan suture, and its northern boundary as a

835 Cadomian suture re-activated in Variscan times.

836

\section{Acknowledgements}

838 This research was supported by the Spanish Ministry of Science project CGL2006-12259, the

839 Consolider-Ingenio 2010 program, under CSD2006-00041 "Topo-Iberia" and by Acciones

840 Integradas Hispano-Portuguesas. Critical comments from Alan Jones, Ian Fergusson, Philip

841 Wannamaker and an anonymous reviewer contributed significantly to clarify the ideas 842 presented in this paper and are deeply acknowledged.

843

844

845

846

847

848

849

850

851

852

853

854

855

856

857

858

\section{References}

Almeida, E., J. Pous, F. Monteiro Santos, P. Fonseca, A. Marcuello, P. Queralt, R. Nolasco, and L. Mendes Victor (2001), Electromagnetic imaging of a transpressional tectonics in SW Iberia, Geophys. Res. Lett., 28, 439-442.

Almeida, E., F. Monteiro Santos, A. Mateus, W. Heise, and J. Pous (2005), Magnetotelluric measurements in SW Iberia: new data for the Variscan crustal structures analyses, Geophys. Res. Lett.,32, L08312, doi: 10.1029/2005GL022596.

Apalategui, O., L. Eguiluz and C. Quesada (1990), Structure, in Pre-Mesozoic Geology of Iberia, edited by R.D. Dallmeyer and E. Martinez-Garcia, pp. 280-291, Springer-Verlag, Berlin. 
859

860

861

862

863

864

865

866

867

868

869

870

871

872

873

874

875

876 Carbonell, R., F., Simancas, C. Juhlin, J. Pous, A. Pérez-Estaún, F. González-Lodeiro, G.

877 Muñoz, W. Heise, and P. Ayarza (2004), Geophysical evidence of a mantle derived intrusion

878 in SW Iberia, Geophys. Res. Lett., 31, L11601 doi:10.1029/2004GL019684.

879

880 Carretero, R.S., L. Eguíluz, E. Pascual and M. Carracedo (1990), Igneous rocks in Pre-

881 Mesozoic Geology of Iberia, edited by R.D. Dallmeyer and E. Martinez-Garcia, pp. 292-313,

882 Springer-Verlag, Berlin.

Araújo, A. (1995), Estrutura de uma geotransversal entre Brinches e Mourão (Zona de Ossa-

Araújo, A. and A. Ribeiro (1995), Tangential transpressive strain regime in the ÉvoraAracena Domain (Ossa Morena Zone), Bol. Geol. y Minero, 106, 111-117

Araújo, A., P. Fonseca, J. Munhá, P. Moita, J. Pedro and A. Ribeiro (2005), The Moura Phyllonitic Complex: an accretionary complex related with obduction in the Southern Iberia Variscan Suture, Geodin. Acta, 18/5, 375-388.

Avdeev, D.B. (2005), Three-dimensional electromagnetic modeling and inversion from theory to application, Surv. Geophysics, 26, 767-799.

Beaumont, C. and G. Quilam (1994), A geodynamic framework for interpreting crustal-scale seismic-reflectivity patterns in compressional orogens, Geophys. J. Intern., 116, 754-783.

883 
884 Castro, A., C. Fernández, H. El-Himdi, M. El-Biad, M. Díaz, J.D. De la Rosa and F. Stuart F. 885 (1999), Age constraints to the relationships between magmatism, metamorphism and 886 tectonism in the Aracena metamorphic Belt, Southern Spain, Intern. Journ. Earth Sci., 88, 26$887 \quad 37$.

Cebriá, J.M., J. López-Ruiz, M. Doblas, L.T. Martins and J. Munhá (2003), Geochemistry of the Early Jurassic Messejana-Placencia dyke (Portugal - Spain); implications on the origin of the Central Atlantic Magmatic Province, J. Petrol., 44, 547-568.

892

Coney, P., D.L. Jones and J.W.H. Monger (1980), Cordilleran suspect terranes, Nature, 288, 894 329-333.

895

896 Constable, S. and C. Constable (2004), Observing geomagnetic induction in magnetic satellite measurements and associated implications for mantle conductivity, Geochem. Geophys. 898 Geosyst., 5, Q01006, doi:10.1029/2003GC000634.

899

900 Cook, F. (1984), Geophysical anomalies along strike of the southern Appalachian piedmont. 901 Tectonics, 3, 45-62.

902

Díaz Aspiroz, M., A. Castro, C. Fernández, S. López, J.C. Fernández Caliani and I. Moreno-

904 Ventas (2004), The contact between the Ossa Morena and the South Portuguese zones.

905 Characteristics and significance of the Aracena metamorphic belt in its central sector between 906 Aroche and Aracena (Huelva), Journal of Iberian Geology, 30, 25-51. 
908 Egbert, G. and J.R. Booker, (1986), Robust estimation of geomagnetic transfer functions,

910

911 Egbert, G. and J.R. Booker (1992), Very long period magnetotellurics at Tucson observatory,

912 J. Geophys. Res., 97, 3397-3404.

913

914 Eguíluz, L., J.I. Gil Ibarguchi, B. Ábalos and A. Apraiz (2000), Superposed Hercynican and 915 Cadomian orogenic cycles in the Ossa-Morena Zone and related areas of the Iberian Massif, 916 GSA Bulletin, 112 (9), 1398-1413.

917

918 Eisel, M. and V. Haak. (1999), Macro-anisotropy of the electrical conductivity of the crust: a 919 magnetotelluric study of the German Continental Deep Drilling Site (KTB), Geophys. J. Int., $920136,109-122$.

921

922 England, P., and D. McKenzie (1982), A thin viscous sheet model for continental 923 deformation, Geophys. J. R. astr. Soc., 70, 295-321.

924

925 Evans, S., A.G. Jones, J. Spratt and J. Katsube (2005), Central Baffin electromagnetic 926 experiment (CBEX) maps the NACP in the Canadian arctic, Phys. Earth Planet. Int., 150, $927 \quad 107-122$.

928

929 Farias, P., G. Gallastegui, F. González Lodeiro, J. Marquínez, L.M. Martín Parra, J.R. 930 Martínez Catalán, J.G. Pablo Macia and L.R. Rodríguez Fernández (1987), Aportaciones al 931 conocimiento de la litoestratigrafia y estructura de Galicia Central. Mem. Fac. Ciências Univ. 932 Porto, 1, 411-431. 
934 Fernández-Suaréz, G., G. Gutiérrez Alonso, G. Jener, and M. N. Tubrett (2000), New ideas on 935 the Proterozoic-Early Paleozoic evolution of NW Iberia: insights from U-Pb detrital zircon 936 ages, Precambrian Res., 102, 185-206.

937

938 Figueiras, J., A. Mateus, M. A. Gonçalves, J. C. Waerenborgh, and P. Fonseca (2002), 939 Geodynamic evolution of the South Variscan Iberian Suture as recorded by mineral 940 transformations, Geodin. Acta, 15, 45-61.

941

942 Fonseca P. (1995), Estudo da sutura Varisca no SW Ibério nas regiões de Serpa-Beja-Torrão e 943 Alvito-Viana do Alentejo, PhD Thesis, Univ. Lisboa, Lisboa, Portugal.

944

945 Fonseca, P., J. Munhá, J. Pedro, F. Rosas, P. Moita, A. Araújo, and N. Leal (1999), Variscan 946 ophiolites and high-pressure metamorphism in Southern Iberian, Ophioliti, 24, 259-268

948 Franke, W. (1989), Tectonostratigraphic units ins the Variscan belt of Central Europe, in 949 Terranes in the Circum-Atlantic Paleozoic Orogens, Special Papers, vol. 230, edited by R. D. 950 Dallmeyer, pp. 67-90, Geological Society of America.

951

952 Franke, W. (2000), The mid-European segment of the Variscides: tectonostratigraphic units, 953 terrane boundaries and plate tectonic evolution, in Orogenic Processes: quantification and 954 modeling, Variscan Belt, Spec. Publ. vol.179, edited by W. Frank, V. Haak, O. Oncken and 955 D. Tanner, pp. 35-64, Geol. Soc. London.

956 
957 Grocott, J., K.J.W. McCaffrey, G.K. Taylor and B. Tikoff (2004), Vertical coupling and 958 decoupling in the lithosphere, in Vertical Coupling and Decoupling in the Lithosphere, 959 Special Publications, vol. 227, edited by J. Grocott, K.J.W. McCaffrey, G.K. Taylor and B. 960 Tikoff, pp. 1-7, Geological Society, London.

962 Harry, D.L., J.S. Oldow and D.S. Sawyer (1995), The growth of orogenic belts and the role of 963 crustal heterogeneities in decollement tectonics, Geol Soc. Amer. Bull., 107, 1411-1426.

964

965 Heise, W. and J. Pous (2001), Effects of anisotropy on the two-dimensional inversion 966 procedure, Geophys. J. Int., 147, 610-621.

967

968 Heise, W. and J. Pous (2003), The anisotropic modeling of phase anomalies exceeding 90 ${ }^{\circ}$ : A 969 field data application, Geophys. J. Int., 155, 308-318.

970

971 Hoffman-Rothe, A., O. Ritter and V. Haak (2001), Magnetotelluric and geomagnetic 972 modeling reveals zones of very high electrical conductivity in the upper crust of Central Java, 973 Physics of the Earth Int., 124, 131-151.

974

975 Houseman, G. and P. England (1986), Finite strain calculations of continental deformation, 1, 976 method and general results for convergent zones, J. Geophys. Res., 91, 3621-3663.

977

978 Jesus, A., J. Munhá, A. Mateus, C. Tassinari and A. P. Nutman (2007), The Beja Layered 979 Gabbroic Sequence (Ossa Morena Zone, Southern Portugal): geochronology and geodynamic 980 implications, Geodin. Acta, 20/3, 139-157. 
982 Jones, A. (1998), Waves of future: Superior inferences from collocated seismic and 983 electromagnetic experiments, Tectonophysics, 286, 273-298.

984

985

Jones, A.G., T.J. Katsube and P. Schwann (1997), The longest conductivity anomaly in the 986 world explained: sulphides in fold hinges causing very high electrical anisotropy. J. Geomag. 987 Geoelectr., 49, 1619-1629.

988

Julivert, M., J.M. Fontboté, A. Ribeiro and L.S. Conde (1974), Mapa Tectónico de la 990 Península Ibérica y Baleares a escala 1:1.000.000. IGME, Madrid.

991

992 Julivert M., F.J. Martínez and A. Ribeiro (1980), The Iberian segment of the European 993 Hercynian Foldbelt, in Géologie de l'Europ, Mémories du BRGM, vol. 108, edited by J. 994 Cogné and M. Slansky, pp. 132-158, Société Géologique du Nord / BRGM.

995

996 López-Munguira, A. and F. Nieto Garcia (2004), Low-grade metamorphism in the central 997 sector of the Ossa-Morena Zone, Journal of Iberian Geology, 30, 109-118.

998

999 Lötze, F. (1945), Zur gliederung dês Variscides der Iberischen Meseta, Geotektonische 1000 Forschungen, 6, 78-92.

1001

1002 Mackie R.L. and T.R. Madden (1993), Three dimensional magnetotelluric inversion using 1003 conjugated gradient, Geophys. J. Int., 115, 215-229.

1004

1005 Mackie, R.L. and J.R. Booker (1999), Documentation for mtd3fwd and d3-to-mt, GSY-USA, 1006 Inc., 226 Market St. 643, San Francisco, CA 94114. 
1008 Mackie, R.L., Madden, T.R. and P.E. Wannamaker (1993), Three-dimensional 1009 magnetotelluric modeling using difference equations - Theory and comparisons to integral 1010 equation solutions, Geophysics, 58, 215-226.

1011

1012 Mateus, A., J. Figueiras, M. A. Gonçalves, and P. Fonseca (1999), Evolving fluid circulation 1013 within the Variscan Beja-Acebuches Ophiolite Complex (SE, Portugal), Ofioliti, 24, 269-282 1014

1015 Matte, Ph. (1986), Tectonics and plate tectonics for the Variscan Fold Belt in Western 1016 Europe. Tectonophysics, 126, 329-374.

1017

1018 Matte, Ph. (2001), The Variscan collage and orogeny (480-290 Ma) and the tectonic 1019 definition of the Armorica microplate: a review, Terra Nova, 13, 122-128.

1020

1021 McNeice, G. and A. G. Jones (2001), Multisite, multifrequency tensor decomposition of 1022 magnetotelluric data, Geophysics, 66, 158-173.

1023

1024 Moita P., J. Munhá, P. Fonseca, J. Pedro, C.C.G. Tassinari, A. Araújo and T. Palácios 1025 (2005a), Phase equilibria and geochronology of Ossa-Morena eclogites, paper presented at 1026 XIV Semana de Geoquímica / VIII Congresso de Geoquímica dos Países de Língua 1027 Portuguesa, Aveiro, Portugal, 463-466.

1028

1029 Moita P., J. Munhá, P. Fonseca, C.C.G. Tassinari, A. Araújo and T. Palácios (2005b), Dating 1030 orogenic events in Ossa-Morena Zone, paper presented at XIV Semana de Geoquímica / VIII 1031 Congresso de Geoquímica dos Países de Língua Portuguesa, Aveiro, Portugal, 459-461. 
1033 Moita P., J.F. Santos and M.F. Pereira (2005c), Dados geocronológicos de rochas intrusivas 1034 sin-tectónicas do Maciço dos Hospitais (Montemor-o-Novo, Zona de Ossa-Morena), paper 1035 presented at XIV Semana de Geoquímica / VIII Congresso de Geoquímica dos Países de 1036 Língua Portuguesa, Aveiro, Portugal, 471-474

1037

1038 Monteiro Santos, F.A., J. Pous, E.P. Almeida, P. Queralt, A. Marcuello, H. Matías and L. A. 1039 Mendes Victor (1999), Magnetotelluric survey of the electrical conductivity of the crust 1040 across the Ossa Morena Zone and South Portuguese Zone suture, Tectonophysics, 313, 4491041462.

1042

1043 Monteiro Santos, F.A., A. Mateus, E.P. Almeida, J. Pous and L.A. Mendes-Victor (2002), 1044 Are some of the deep crustal conductive features found in SW Iberia caused by graphite?, 1045 Earth Planet. Sci. Lett., 201, 353-367.

1047 Monteiro Santos, F. A., A. Soares, R. Noslasco, H. Rodrigues, R. Luzio, N. Palshin and the 1048 ISO-3D team (2003), Lithosphere conductivity structure using the CAM-1 (Lisbon-Madeira) 1049 submarine cable, Geophys. J. Int., 155, 591-600.

1050

1051 Munhá, J., A. Ribeiro, P. Fonseca, J.T. Oliveira, P. Castro and C. Quesada (1989), Accreted 1052 terranes in Southern Iberia: Beja-Acebuches ophiolite and related oceanic sequences, paper 1053 presented at $28^{\text {th }}$ Int. Geol. Cong., Washington, U.S.A., 481-482. 
1055 Muñoz, G., W. Heise, C. Paz, E. Almeida, F. Monteiro Santos and J. Pous (2005), New

1056 magnetotelluric data trough the boundary between the Ossa Morena and Centroiberian Zones,

1057 Geologica Acta, 3, 215-223.

1058

1059 Oldow, J.S., A.W. Bally and H.G. Ave Lallemant (1990), Transpression, orogenic float and

1060 lithospheric balance, Geology, 18, 991-994.

1061

1062 Oliveira, J.T. (1990), Stratigraphy and syn-sedimentary tectonism in the South Portuguese

1063 Zone, in Pre-Mesozoic Geology of Iberia, edited by R.D. Dallmeyer and E. Martinez-Garcia,

1064 pp. 334-347, Springer-Verlag, Berlin.

1065

1066 Oliveira, J.T., V. Oliveira and J.M. Piçarra (1991), Traços gerais da evolução tectono-

1067 estratigráfica da Zona de Ossa-Morena, em Portugal, Cuad. Lab. Xeológico de Laxe, 16, 2211068250.

1069

1070 Oliveira, V., J. Matos, C. Rosa (2001), The NNW sector of the Iberian Pyrite Belt - new 1071 exploration perspectives for the next decade, in Massive Sulphide Deposits in the Iberian 1072 Pyrite Belt: New Advances and Comparison with Equivalent Systems, Proceedings of 1073 GEODE Workshop, edited by F. Tornos, E. Pascual, R Saéz and R Hidalgo, pp. 34-37, Univ. 1074 Huelva, Aracena (Spain).

1075

1076 Oliveira, J.T., Z. Pereira, P. Carvalho, N. Pacheco and D. Korn (2004), Stratigraphy of the 1077 tectonically imbricated lithological succession of the Neves Corvo mine área, Iberian Pyrite 1078 Belt, Portugal, Mineral. Deposita, 39, 422-436. 
1080 Olsen, N. (1998), The electrical conductivity of the mantle beneath Europe derived from $C$ 1081 responses from 3 to 720 hr, Geophys. J. Int., 133, 298-308.

1082

1083 Pereira, M.F., M. Chichorro, U. Linnemann, L. Eguíluz and J.B. Silva (2006a), Inherited arc 1084 signature in Ediacaran and Early Cambrian basins of the Ossa-Morena Zone (Iberian Massif, 1085 Portugal): paleogeographic link with European and North African Cadomian correlatives, 1086 Precambrian Res., 144, 297-315.

1087

Pereira, Z., V. Oliveira and J.T. Oliveira (2006b), Palynostratigraphy of the Toca da Moura and Cabrela Complexes, Ossa Morena Zone, Portugal. Geodynamic implications. Rev. Palaeobot. Palynology, 139, 227-240

1091

Pin, C., J.-L. Paquette and P. Fonseca (1999), $350 \mathrm{Ma}$ (U-Pb zircon) igneous emplacement age and Sr-Nd isotopic study of the Beja gabbroic complex (S. Portugal), paper presented at XV Reunion de Geologia del Oeste Peninsular, Diputación de Badajoz, Badajoz, Spain, 190194.

Pous, J., G. Muñoz, W. Heise, J.C Melgarejo, and C. Quesada (2004), Electromagnetic imaging of Variscan crustal structures in SW Iberia: the role of interconnected graphite, Earth Planet. Sci. Lett., 217, 435-450.

1101 Prodehl, C., V.S. Moreira, St. Mueller and A.S. Mendes (1975), Deep-seismic sounding experiments in Central and Southern Portugal, paper presented at $14^{\text {th }}$ General Assembly of the European Seismological Commission, Berlin, 261-266. 
1105 Queralt, P., A.G. Jones, and J. Ledo (2007), Electromagnetic imaging of a complex ore body:

1106 three-dimensional forward modelling, sensitivity tests and down-mine measurements,

1107 Geophysics, 72, 85-95.

1108

1109 Quesada, C. (1991), Geological constraints on the Paleozoic tectonic evolution of

1110 tectonostratigraphic terranes in the Iberian Massif, Tectonophysics, 185, 225-245.

1111

1112 Quesada, C. (1998), A reappraisal of the structure of the Spanish segment of the Iberian Pyrite

1113 Belt, Mineral. Deposita, 33, 31-44.

1114

1115 Quesada, C. and J. Munhá (1990), Metamorphism, in Pre-Mesozoic Geology of Iberia, edited

1116 by R.D. Dallmeyer and E. Martinez-Garcia, pp. 314-320, Springer-Verlag, Berlin.

1117

1118 Quesada, C., P. Fonseca, J. Munhá, J. T. Oliveira, and A. Ribeiro (1994), The Beja-

1119 Acebuches Ophiolite (Southern Iberian Variscan fold belt): geologic characterization and 1120 geodynamic significance, Bol. Geol. Min., 105, 3-44.

1121

1122 Rannali, G. and D.C. Murphy (1987), Rheological stratification of the lithosphere,

1123 Tectonophysics, 132, 281-295.

1124

1125 Ribeiro, A. (1981), A geotransverse through the Variscan fold belt in Portugal, in The

1126 Variscan Orogen in Europe, Geol. Mijnbouw, vol. 60, edited by H.J. Zwart and V.F.

1127 Dornsiepen, pp. 41-44.

1128 
1129 Ribeiro, A. (2000), Geodynamic evolution of Iberian Variscides: unsolved questions, in

1130 Variscan-Appalachian dynamics: the building of the Upper Paleozoic basement, paper 1131 presented at GALICIA 2000, Basement Tectonics 15, A Coruña, Spain.

1133 Ribeiro A., J.B. Silva (1983), Structure of the South Portuguese Zone, in The Carboniferous 1134 of Portugal, Mem. Serv. Geol. Portugal, 29, edited by M.J. Lemos de Sousa and J. T. 1135 Oliveira, pp. 83-89.

Ribeiro A., C. Quesada and R.D. Dallmeyer (1990), Geodynamic evolution of the Iberian

1138 Massif, in Pre-Mesozoic Geology of Iberia, edited by R.D. Dallmeyer and E. Martinez1139 Garcia, pp. 397-410, Springer-Verlag, Berlin, Germany.

1141 Ribeiro A., J. Munhá, R., Dias, A. Mateus, E. Pereira, L. Ribeiro, P. Fonseca, A. Araújo, J.T.

1142 Oliveira, J. Romão, H. Chaminé, C. Coke and J. Pedro (2007), Geodynamic evolution of the 1143 SW Europe Variscides, Tectonics, 26, doi:10.1029/2006TC002058.

1145 Robardet, M. and J.C. Gutiérrez-Marco (2004), The Ordovician, Silurian and Devonian 1146 sedimentary rocks of the Ossa-Morena Zone (SW Iberian Peninsula, Spain), Journal of 1147 Iberian Geology, 30, 73-92.

1148

1149 Salman, K. (2004), The timing of the Cadomian and Variscan Cycles in the Ossa-Morena 1150 Zone, SW Iberia: granitic magmatism from subduction to extension, Journal of Iberian 1151 Geology, 30, 119-132. 
1153 San José, M.A., P. Herranz and A.P. Pieren (2004), A review of the Ossa-Morena and its

1154 limits. Implications for the definition of the Lusitan-Marianic Zone, Journal of Iberian 1155 Geology, 30, 7-22.

1157 Sanderson, D. and R.D. Marchini (1984), Transpression, J. Struct. Geol., 6, 449-458.

1158

1159 Sasaki, Y. (2004), Three-Dimensional Inversion for Large-Scale Structure in a Spherical 1160 Domain, Earth Planet. Spaces, 56, 239-248.

1162 Silva, J.B. and M.F. Pereira (2004), Transcurrent continental tectonics model for the Ossa1163 Morena Zone Neoproterozoic-Paleozoic evolution, SW Iberian Massif, Portugal, Int. J. Earth 1164 Sci., 93, 886-896.

1165

1166 Simancas, F., D. Martínez Poyatos, I. Expósito, A. Azor and F. González Lodeiro (2001), The 1167 structure of a major suture zone in the SW Iberian Massif: the Ossa-Morena/Central Iberia 1168 contact, Tectonophysics, 32, 295-308.

1170 Simancas, F., R. Carbonell, F. González Lodeiro, A. Pérez Estaún, C. Juhlin, P. Ayarza, A.

1171 Kashubin, A. Azor, D. Martínez Poyatos, G.R. Almodóvar, E. Pascual, R. Sáez, and I.

1172 Expósito, (2003), The Crustal Structure of the Transpressional Variscan Orogen of SW Iberia:

1173 The IBERSEIS Deep Seismic Profile, Tectonics, 22(6), 1062, doi:10.1029/2002TC001479.

1175 Simancas, F., I. Expósito, A. Azor, D. Martínez Poyatos and F. González Lodeiro (2004),

1176 From the Cadomian orogenesis to the Early Paleozoic Variscan rifting in Southwest Ibéria,

1177 Journal of Iberian Geology, 30, 53-72. 
1179 Simpson F. (2000), A three-dimensional electromagnetic model of the southern Kenya rift:

1180 departure from two dimensionality as a possible consequence of a rotating stress fields, $J$. 1181 Geophys. Res., 105, 19321-19344.

1183 Siripunvaraporn W., G. Egbert, Y. Lenbury and M. Uyeshima (2005), Three-Dimensional

1184 Magnetotelluric Inversion: Data Space Method, Phys. Earth Planet. Int., 150, 3-14.

1186 Tauber S., R. Banks, O. Ritter, U. Weckmann (2003), A high-resolution magnetotelluric 1187 survey of the Iapetus Suture Zone in southwest Scotland., Geophys. J. Int., 153 , 548-568.

1188

1189 Teyssier, C. and L. Cruz (2004), Strain gradients in transpressional to transtensional 1190 attachment zones, in Vertical Coupling and Decoupling in the Lithosphere, Geological 1191 Society, Special Publications, vol. 227, edited by J. Grocott, K.J.W. McCaffrey, G.K. Taylor 1192 and B. Tikoff, pp. 101-115, London.

1193

1194 Teyssier, C., B. Tikoff and J. Weber (2002), Attachement between brittle and ductile crust at 1195 wrenching plate boundaries, in Continental Collision and the Tecton-Sedimentary Evolution 1196 of Forelands, Special Publications, vol. 1, edited by G. Bertotti, K. Schulmann and S. 1197 Cloetingh, pp. 57-73, European Geophysical Society.

1198

1199 Tikoff, B., R. Russo, C. Teyssier and A. Tommasi (2004), Mantle-driven deformation of 1200 orogenic zones and clutch tectonics, in Vertical Coupling and Decoupling in the Lithosphere, 
1201 Special Publications, vol. 227, edited by J. Grocott, K.J.W. McCaffrey, G.K. Taylor and B.

1202 Tikoff, pp. 41-64, Geological Society, London.

1203

1204 Tornos, F. and C. Casquet C. (2005), A new scenario for the related IOCG and Ni-(Cu) 1205 mineralization: the relationship with giant mid-crustal mafic sills, Variscan Iberian Massif, 1206 Terra Nova, 17, 236-241.

1207

1208

Tornos, F., and M. Chiaradia (2004), Plumbotectonic evolution of the Ossa Morena Zone, Iberian Península: tracing the influence of mantle-crust interaction in ore-forming processes,

1210 Econ. Geol., 99, 965-985

1211

1212 Tornos, F., C. Casquet and J.M.R.S. Relvas (2005), Transpressional tectonics, lower crust 1213 decoupling and intrusion of deep mafic sills: a model for the unusual metallogenesis of SW 1214 Iberia, Ore Geology Reviews, 27 (1-4), 133-163.

1215

1216 Varentsov, Iv. M., M. Engels, T. Korja, M. Smirnov, M. Yu. and the BEAR Working Group 1217 (2002), A generalised geoelectrical model of Fennoscandia: a challenging database for long1218 period 3D modellingstudies within the Baltic electromagnetic array research (BEAR) project. 1219 Izvestiya, Physic of the Solid Earth, 38, 11, 855-896.

1220

1221 Vieira da Silva, N., A. Mateus, F. A. Monteiro Santos, E. P. Almeida and J. Pous (2007), 3D 1222 electromagnetic imaging of a Paleozoic plate-tectonic boundary segment in SW Iberian 1223 Variscides (S Alentejo, Portugal), Tectonophysics, in press.

1224 
1225 Wagner, R.H. (2004), The Iberian Massif: a Carboniferous assembly, Journal of Iberian 1226 Geology, 30, 93-108.

1227

1228 Wannamaker, P.E. (2000), Comment on 'The petrologic case for a dry lower crust' by B. W.

1229 D. Yardley and J. W. Valley, J. Geophys. Res., 102, 6057-6064.

1230

1231 Wannamaker, P.E., Stodt, J.A and L.Rijo (1987), A stable finite element solution for two-

1232 dimensional magnetotelluirc modeling, Geophys. Jour. Roy. Astro. Soc, 88, 277-296.

1233

1234 Wannamaker, P.E., G.R. Jiracek, J.A. Stodt, T.G. Caldwell, V.M. Gonzalez, J.D. McKnight 1235 and A.D. Porter (2002), Fluid generation and pathways beneath an active compressional 1236 orogen, the New Zealand Southern Alps, inferred from magnetotelluric data. J. Geophys. 1237 Res., 107, doi:10.1029/2001JB000186.

1238

1239 Willingshofer E., D. Sokoutis and J.-P. Burg (2005), Lithospheric-scale analogue modeling of 1240 collision zones with a pre-existing weak zone, in Deformation Mechanisms, Rheology and 1241 Tectonics: from Minerals to the Lithosphere, Special Publications, vol. 243, edited by D. 1242 Gapais, J.-P. Burg and P.R. Cobbold, pp. 277-294, Geological Society, London.

1244 Xu, Y., T. J. Shankland and B. T. Poe, (2000) Laboratory-based electrical conductivity in the 1245 Earth's mantle, J. Geophys. Res., 105(B12), 27865-27876, 10.1029/2000JB900299. 
1250 Figure 1a - Main geotectonic units of the SW Iberia Variscides (adapted from Quesada, 1251 1991). Grey-shaded area represents the Pre-Mesozoic basement in the Iberian Peninsula; CIZ 1252 - Central Iberian Zone; OMZ - Ossa Morena Zone; SPZ - South Portuguese Zone; PTZ 1253 Porto-Tomar shear zone; TBCS - Tomar-Badajoz-Córdoba shear belt; ET - Exotic Terranes

1254 (PLT and BAOC, Pulo do Lobo Terrane and Beja-Acebuches Ophiolite Complex, 1255 respectively). Thick black lines represent the trace of the main tectonic boundaries with 1256 prevalent thrust or strike-slip displacement.

1258 Figure 1b - OMZ belts (adapted from Simancas et al., 2004). 1- Messejana Fault; 21259 Portalegre-Alegrete Thrust; 3- Hornachos-Villaharta Thrust; 4- Alter do Chão - Campo Maior 1260 Fault; 5- Azuaga Fault; 6- Malcocinado Fault; 7- Monesterio Thrust; 8- Juromenha Thrust; 91261 Beja-Valdelarco Faul; 10- Ferreira Ficalho - Almonaster Thrust; 11- Ficalho-Aroche Fault

1264 Figure 2 - Geological map of OMZ and its boundaries, resulting from an overview of current 1265 OMZ maps available in the Portuguese and Spanish Geological Surveys by using the same 1266 criteria, and plotting features with significance for the geological interpretation reported in the 1267 present paper. 1 - Cenozoic sedimentary cover; 2 - Odovician-Silurian to Carboniferous 1268 sequences in OMZ; 3 - Cambrian sequences in OMZ; 4 - Upper Proterozoic in OMZ; 5 1269 Paleozoic sequences in CIZ; 6 - Paleozoic sequences in SPZ [a) Phyllitic-Quartzitic Group, 1270 Upper Devonian; b) Volcanic-sedimentary Complex, Upper Devonian to Lower Visean; c) 1271 Flysh Group, Upper Visean to Lower Westfalian]; 7 - Exotic Terranes [a) Beja-Acebuches 1272 Ophiolite Complex; b) Pulo do Lobo Terrane]; 8 - Intrusive bodies (mostly granitic in nature 1273 and Variscan in age). Thin black lines represent the traces of the main tectonic discontinuities 1274 (thrust zones and strike-slip fault zones) 
1276 Figure 3 - Simplified geological map and location of the MT sites (dots). The red dots show 1277 the representative sites chosen for the 3D modelization. Legend as in figure 2.

1279 Figure 4a - Data and model responses. Each row corresponds to one kind of data and each 1280 column to one site. Sites $21,16,3,1,10$ and 12 of the new profile I.

1281

1282 Figure 4b - Data and model responses. Each row corresponds to one kind of data and each

1283 column to one site. Sites S09, S24, E06, P04, P34, O04, O19 and L10 (the first letter

1284 corresponds to the name of the profile).

1285

1286 Figure 5 - Real induction arrows (Parkinson convention) at 10, 100 and $1000 \mathrm{~s}$.

1287

1288

Figure 6 - Plan view of the model used for the study of the ocean effect, including the bathymetry. The land part is represented by a 1D model (upper right panel). The induction arrows are shown in Parkinson convention at periods of $20 \mathrm{~s}$ and $100 \mathrm{~s}$.

1291

1292

Figure 7 - Ocean effect in the apparent resistivity and phase curves for the sites closest to the

1293 sea at each profile and one site located far away from the ocean (marked with a star). The

1294 solid line represents the response of the 1D land model.

1295

1296 Figure 8 - Pseudo-sections of the absolute phase difference between data and model 1297 responses for all the profiles. 
1299 Figure 9 - 3D electrical resistivity model. Plan view at different depths. The black dots 1300 indicate the location of the MT sites used for the study. The shore line and the surface 1301 occurrence of the SPZ/OMZ and OMZ/CIZ sutures (see figures 2 and 3) are shown to 1302 facilitate the location of the structures.

1304 Figure 9 (Cont.).

1306 Figure 10 - Plan view of the model at a depth of $22 \mathrm{~km}$ and two cross sections along a NS 1307 profile and an EW profile (Vertical exaggeration $=2$ ). The resistivity values have been 1308 grouped to highlight the most striking conductivity features. Conductors C1, C3 and C6 1309 merge into the conductive layer C9. The black dots indicate the location of the MT sites. The 1310 shoreline and the surface occurrence of the sutures SPZ/OMZ and OMZ/CIZ (see figures 2 1311 and 3) are shown to facilitate the location.

1313 Figure 11 - Data and model responses for different sensitivity tests. The dots represent the 1314 data, the solid lines the responses of the final model (Figs. 9, 10) and the dashed lines the 1315 responses of the altered models: a) Without the resisitive interruption of conductor $\mathrm{C} 3$ in the 1316 south of profile S. b) and c) With a $20 \Omega \mathrm{m}$ layer spanning the whole OMZ from 10 to $30 \mathrm{~km}$

1317 depth instead of the conductive structure of the final model. d) With conductor C6 replaced by 1318 a more extended $20 \Omega \mathrm{m}$ conductive body. 


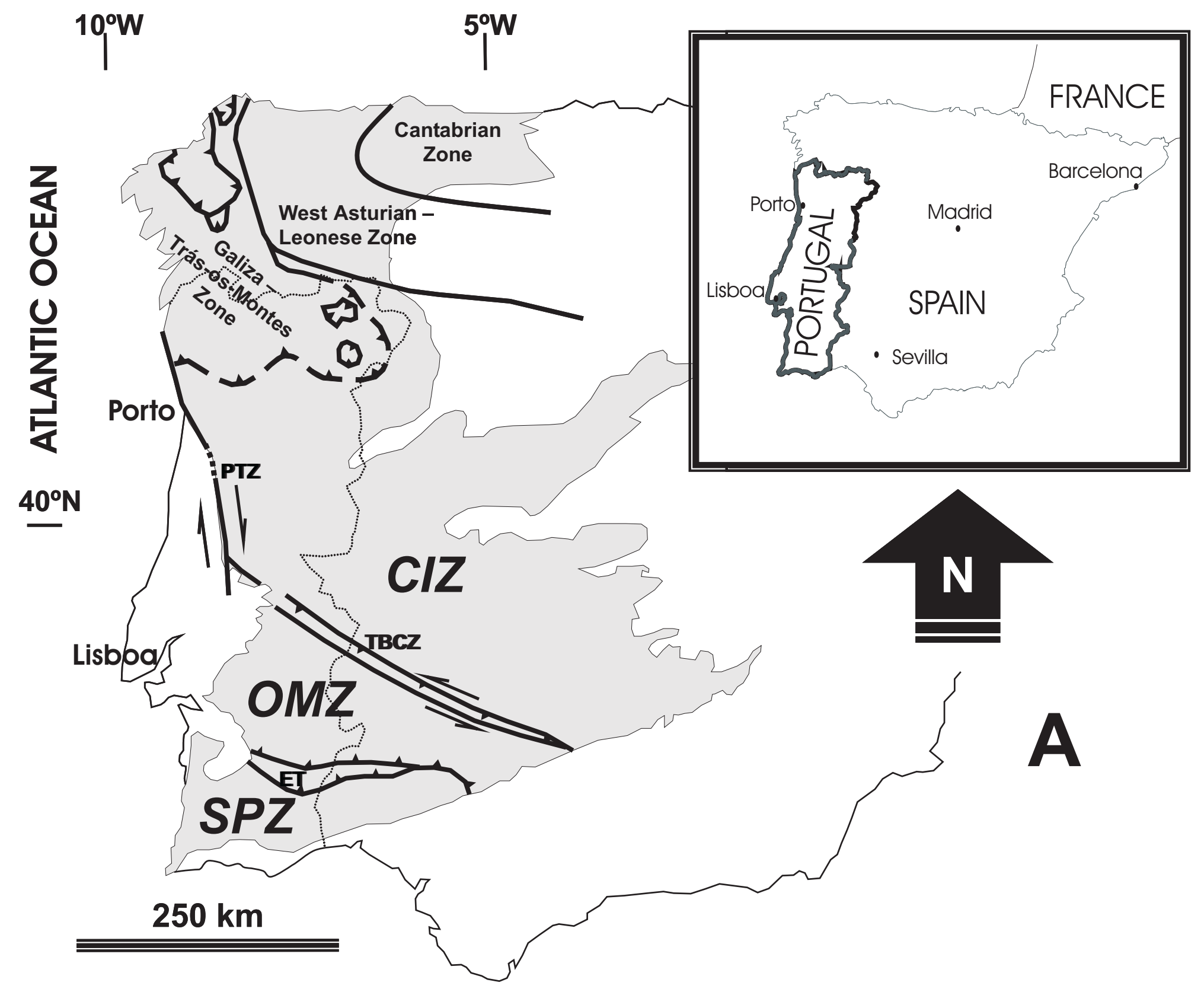

Figure 1a: Main geotectonic units of the SW Iberia Variscides (adapted from Quesada, 1991). Gray-shaded area represents the Pre-Mesozoic basement in the Iberian Peninsula; CIZ Central Iberian Zone; OMZ Ossa Morena Zone; SPZ South Portuguese Zone; PTZ Porto-Tomar shear zone; TBCS Tomar-Badajoz-Córdoba shear belt; ET Exotic Terranes (PLT and BAOC, Pulo do Lobo Terrane and BejaAcebuches Ophiolite Complex, respectively). Thick black lines represent the trace of the main tectonic boundaries with prevalent thrust or strike-slip displacement. 



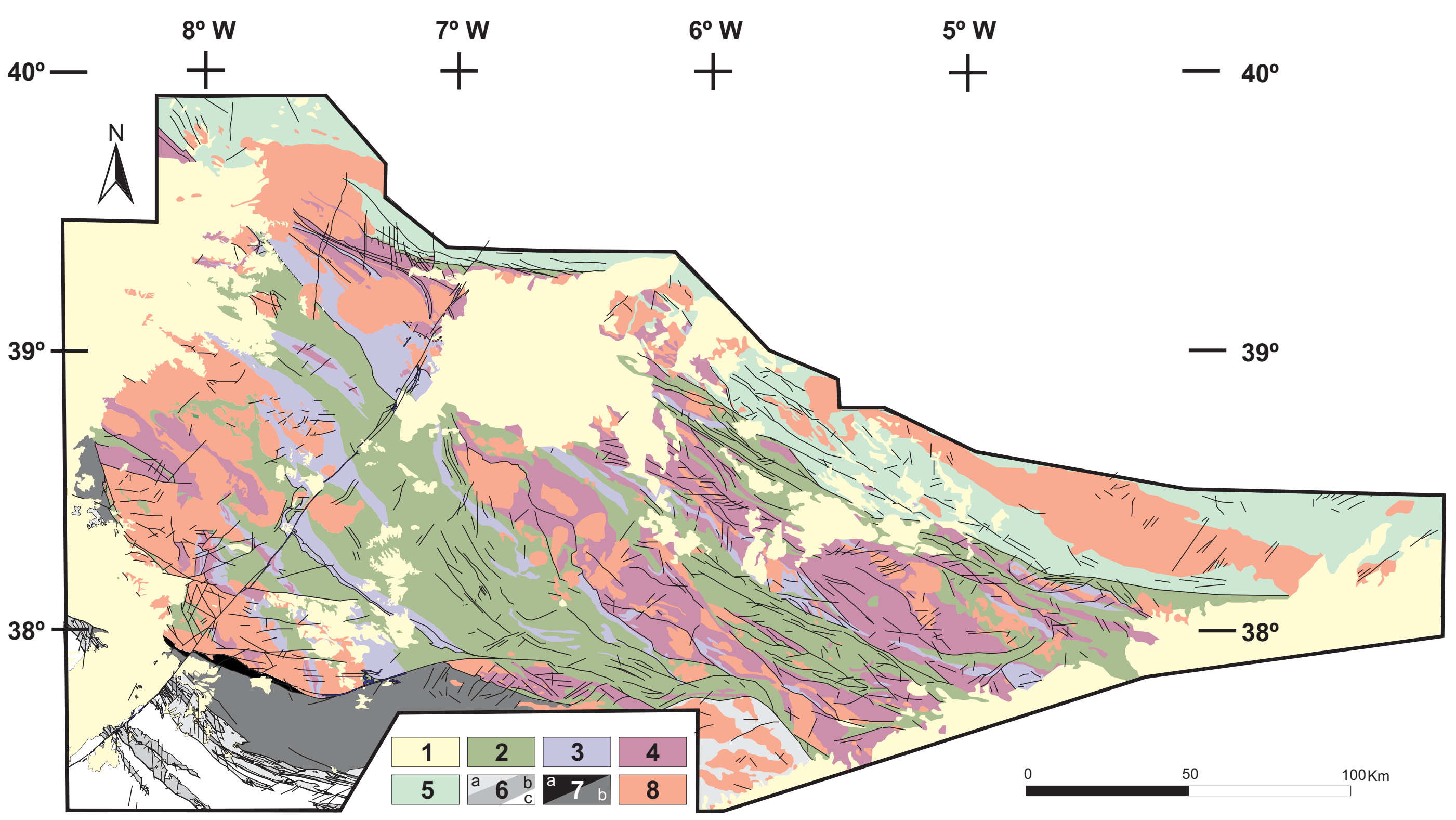

Figure 2: Geological map of OMZ and its boundaries, resulting from an overview of current OMZ maps available in the Portuguese and Spanish Geological Surveys by using the same criteria, and plotting features with significance for the geological interpretation reported in the present paper. 1Cenozoic sedimentary cover; 2 - Odovician-Silurian to Carboniferous sequences in OMZ; 3 - Cambrian sequences in OMZ; 4 - Upper Proterozoic in OMZ; 5 - Palaeozoic sequences in CIZ; 6 - Paleozoic sequences in SPZ [a) Phyllitic-Quartzitic Group, Upper Devonian; b) Volcanic-sedimentary Complex, Upper Devonian to Lower Visean; c) Flysh Group, Upper Visean to Lower Westfalian]; 7- Exotic Terranes [a) Beja-Acebuches Ophiolite Complex; b) Pulo do Lobo Terrane]; 8 - Intrusive bodies (mostly granitic in nature and Variscan in age). Thin black lines represent the traces of the main tectonic discontinuities (thrust zones and strike-slip fault zones) 



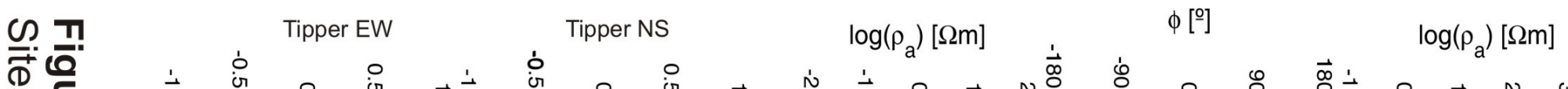

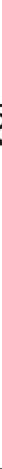

을

을

$\vec{N}$

正 $\overline{0}$

实离

बे

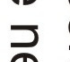

$\sum^{\mathrm{D}} \overline{0}$

<

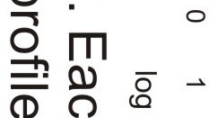

(D)

- 큰

$\bar{\Sigma} \bar{\Omega}^{n}$

8

을
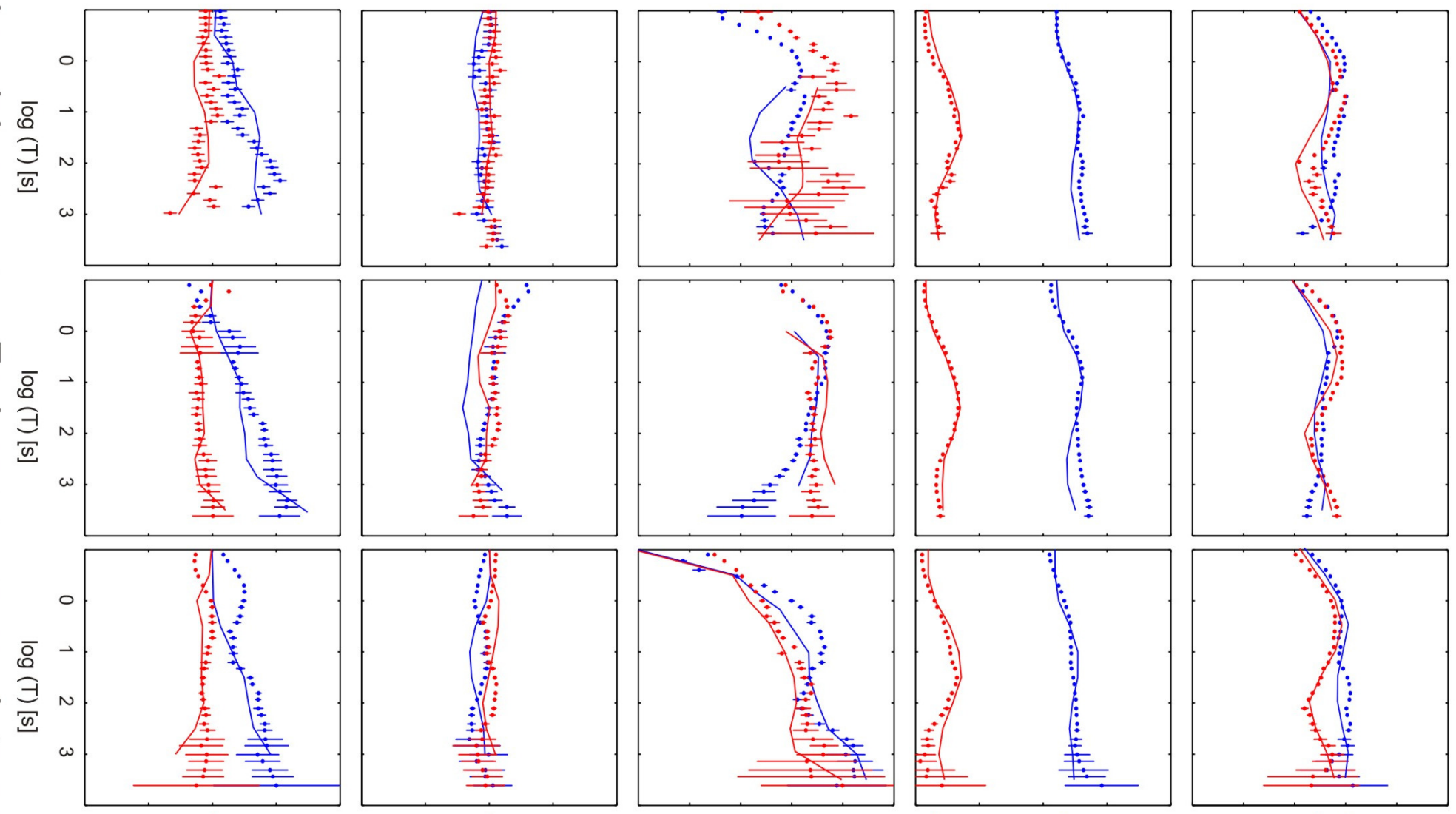

(ำ

즉

좀

응

음

a)

0

$\frac{0}{3}$

.

$$
\text { 害 }
$$

ᄋ
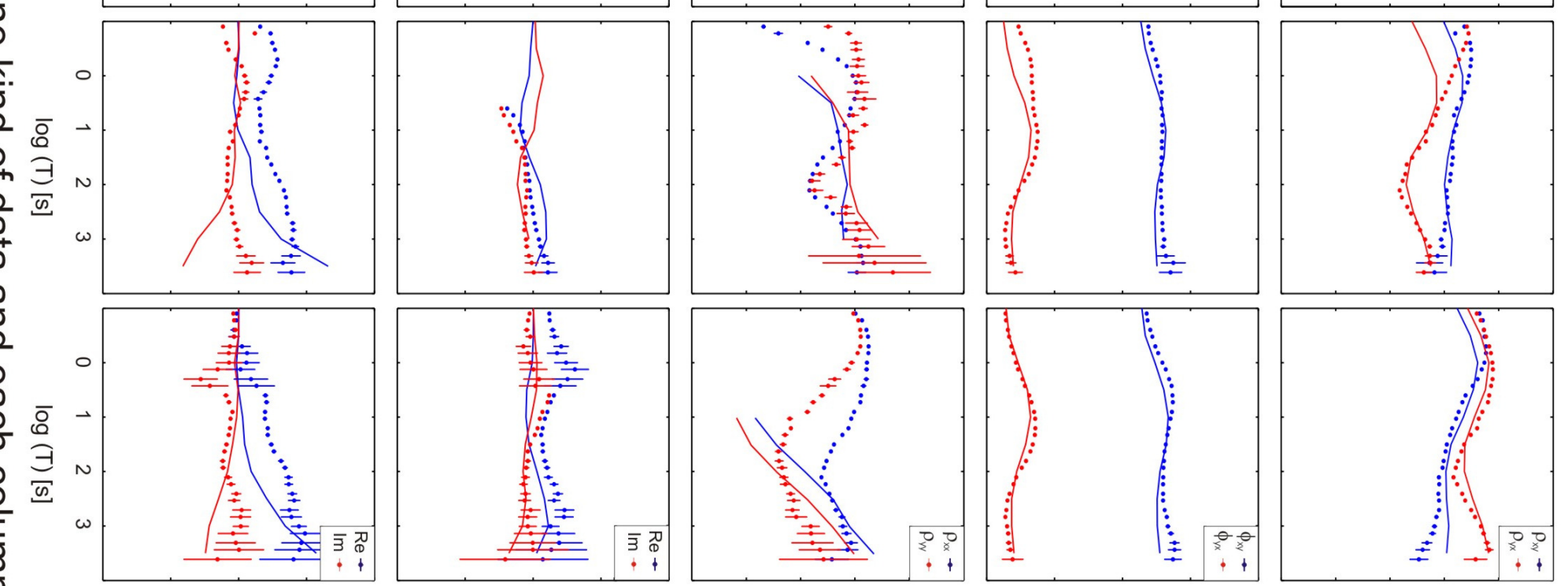

రิ

음

$\frac{\infty}{P}$. 


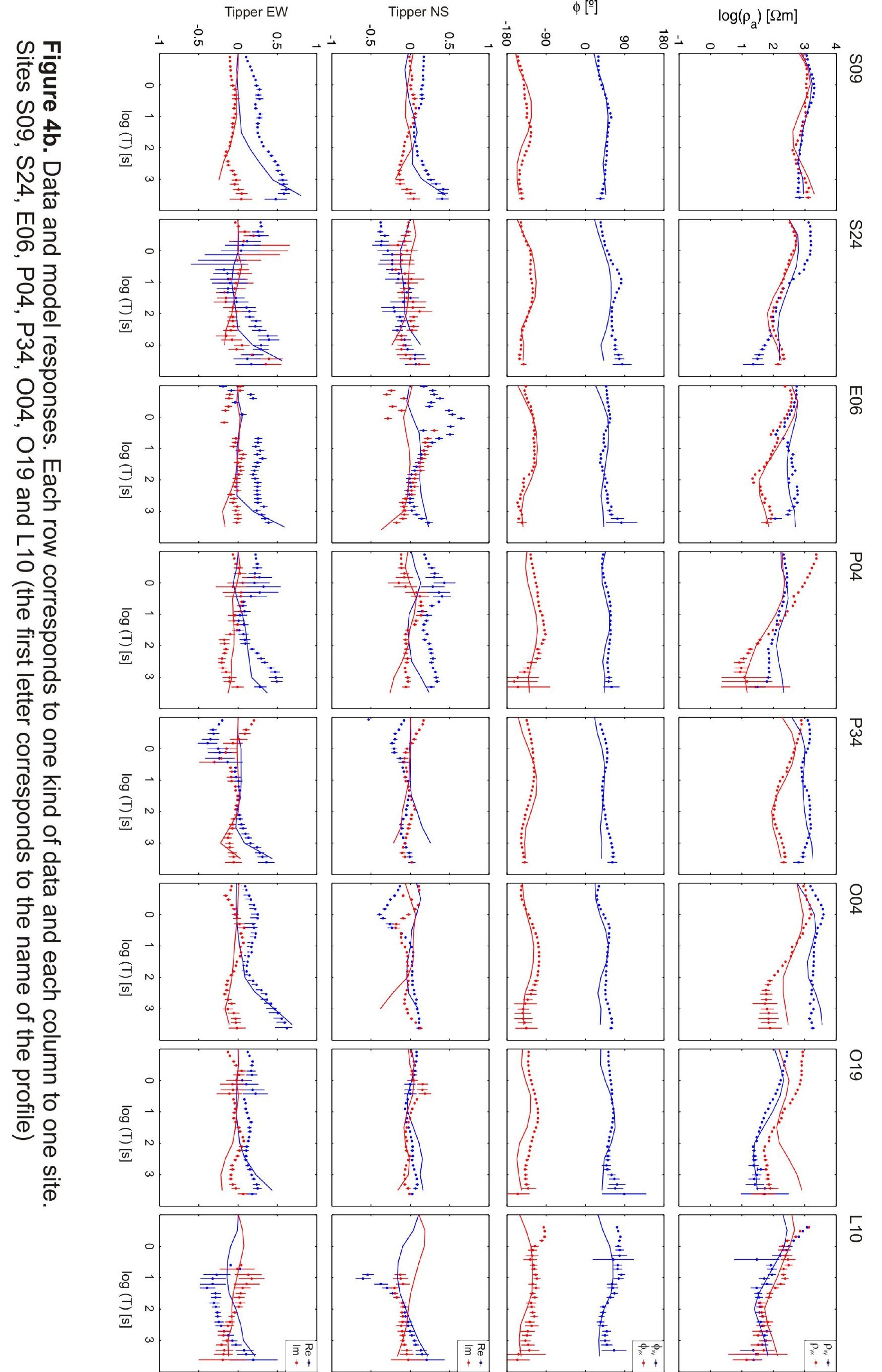



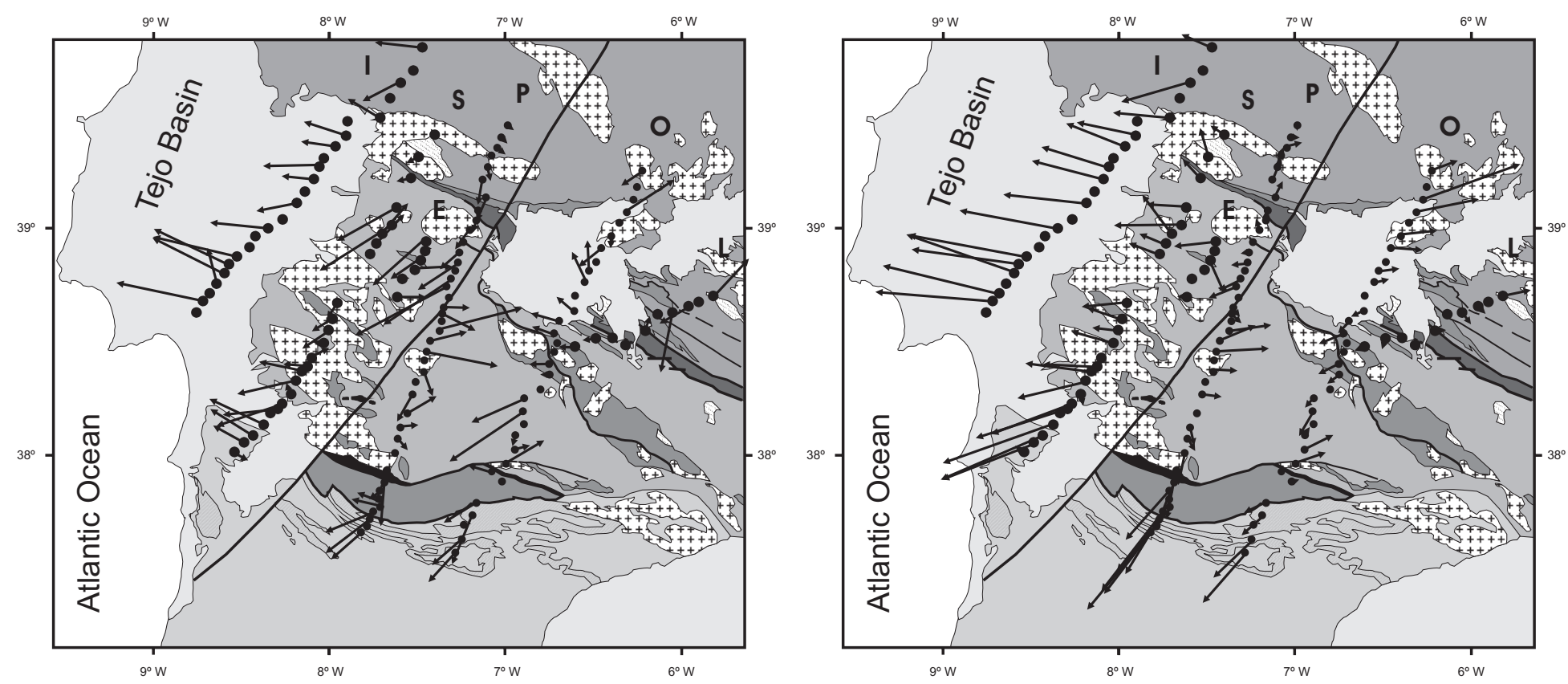

$\mathrm{T}=10 \mathrm{~s}$

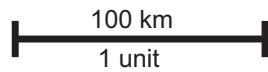

$\mathrm{T}=100 \mathrm{~s}$
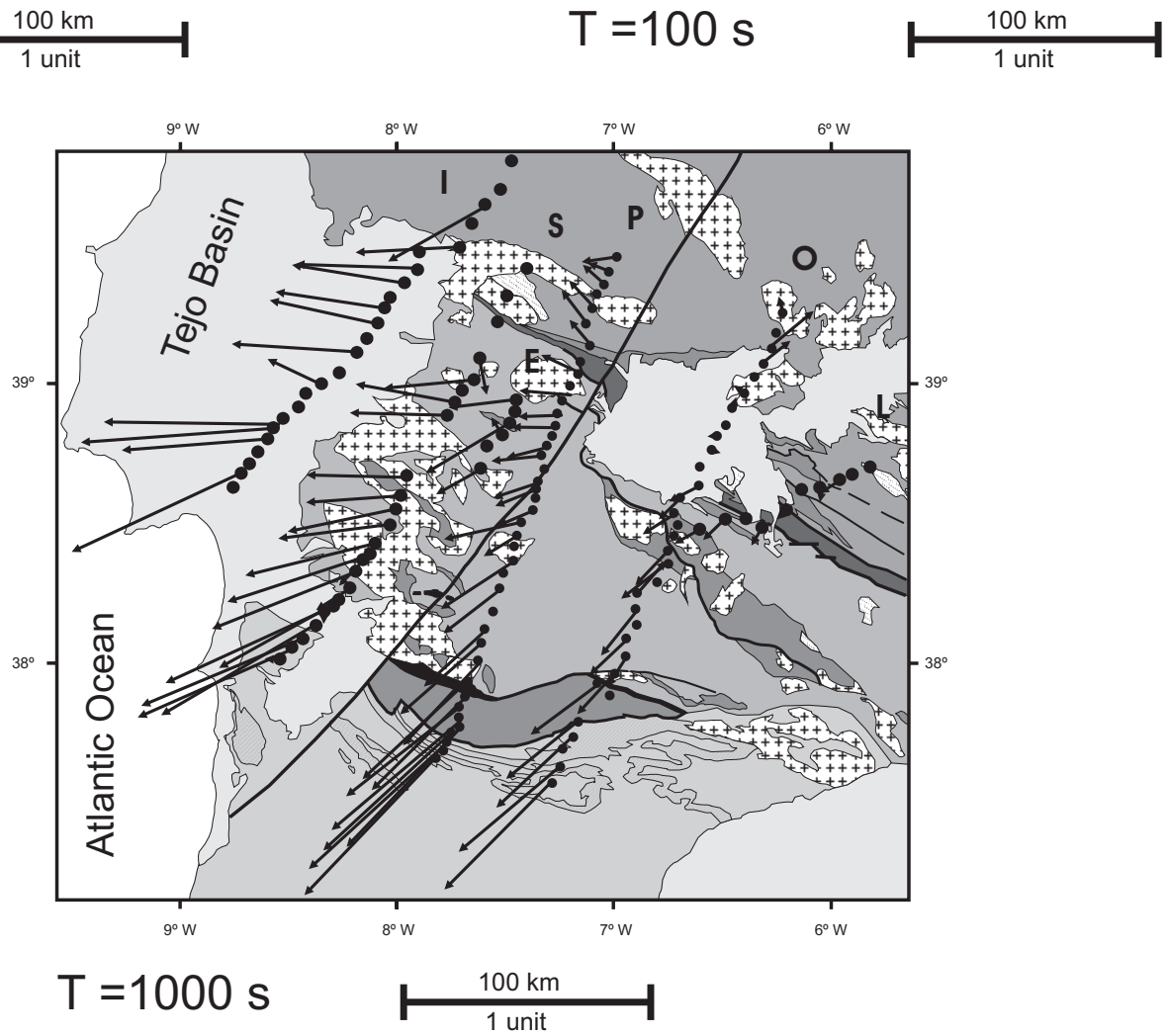

Figure 5. Real induction arrows (Parkinson convention) at 10, 100 and $1000 \mathrm{~s}$. 

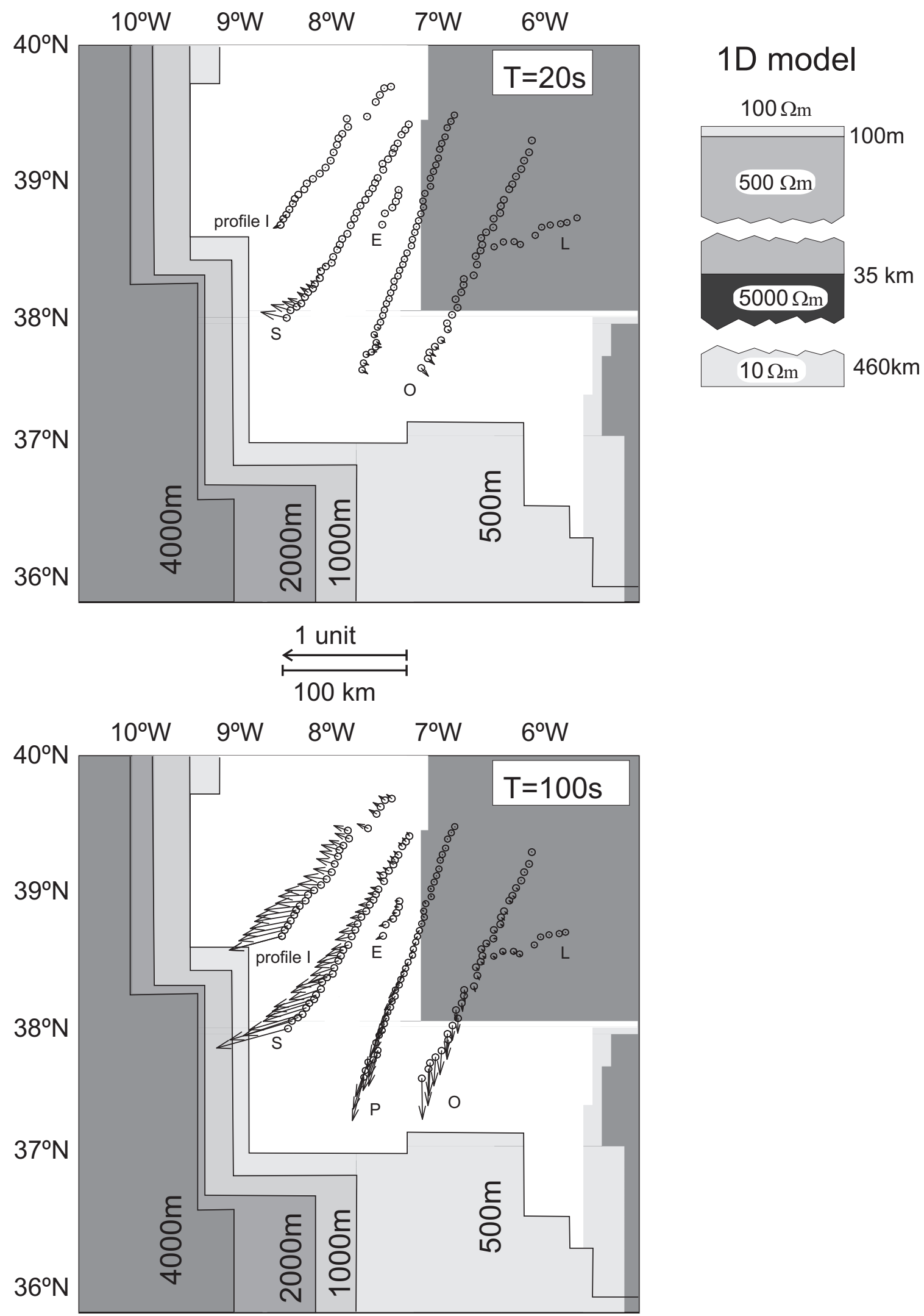

Figure 6. Plan view of the model used for the study of the ocean effect, including the bathymetry. The land part is represented by a 1D model (upper right panel). The induction arrows are shown in Parkinson convention at periods of $20 \mathrm{~s}$ and $100 \mathrm{~s}$. 

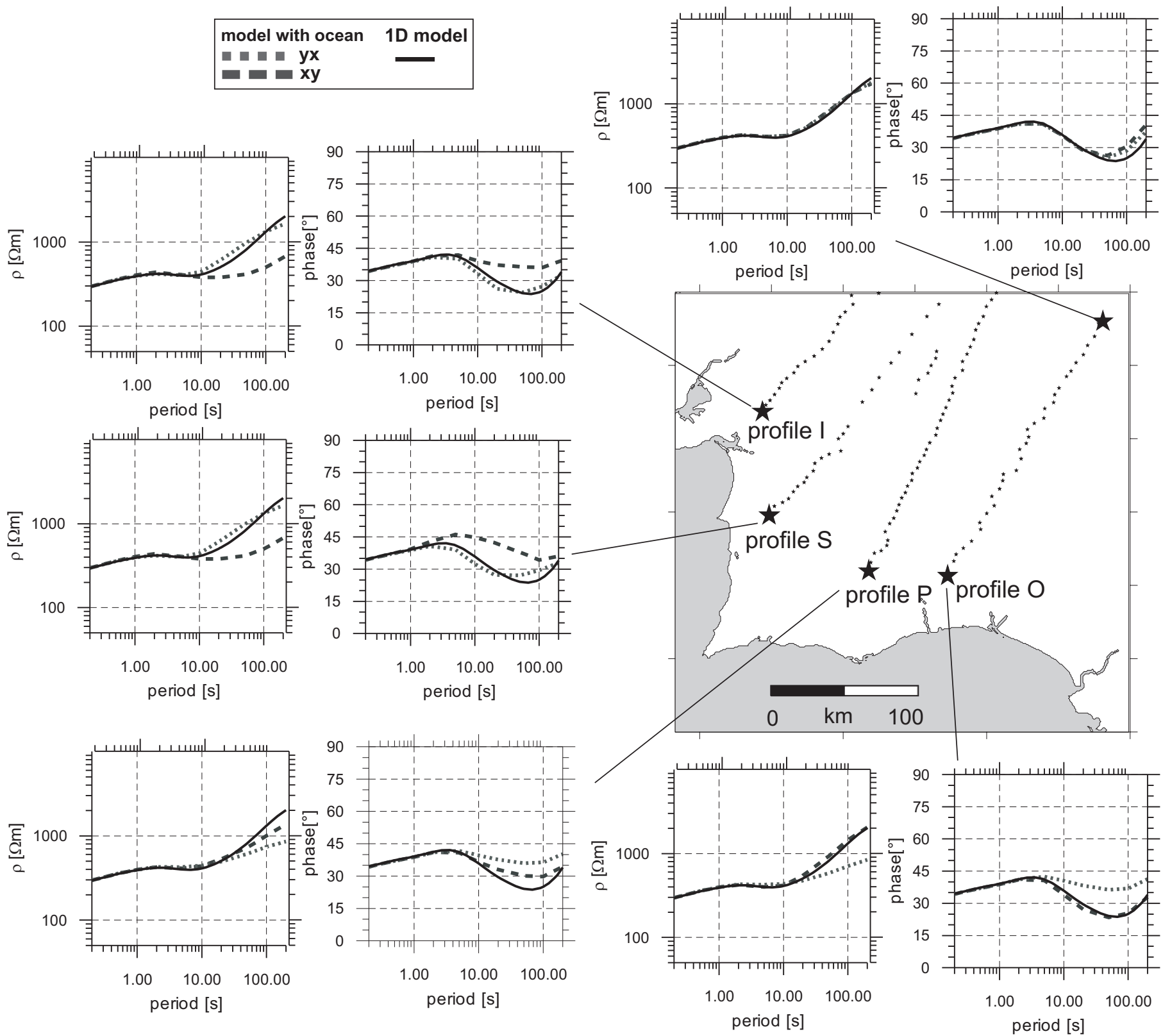

Figure 7. Ocean effect in the apparent resistivity and phase curves for the sites closest to the sea at each profile and one site located far away from the ocean (marked with a star). The solid line represents the response of the 1D land model. 
Phase difference $\left(^{\circ}\right) \mathrm{XY}$

Profile I

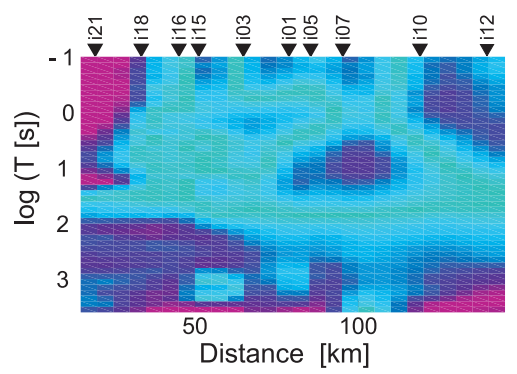

Profile S

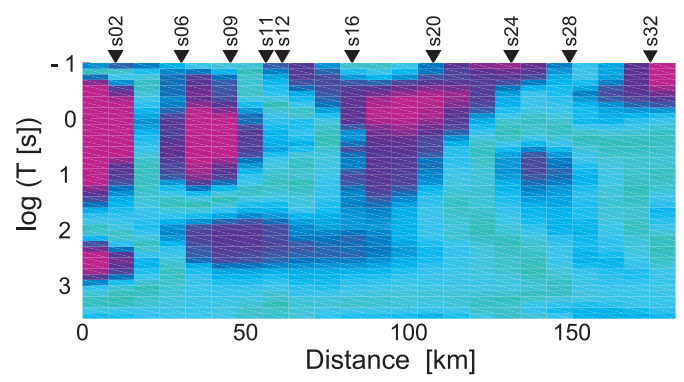

Profile E

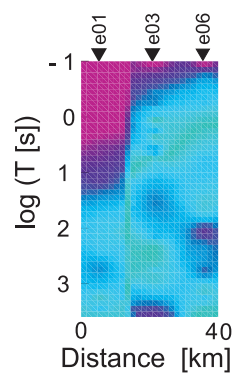

Profile $P$
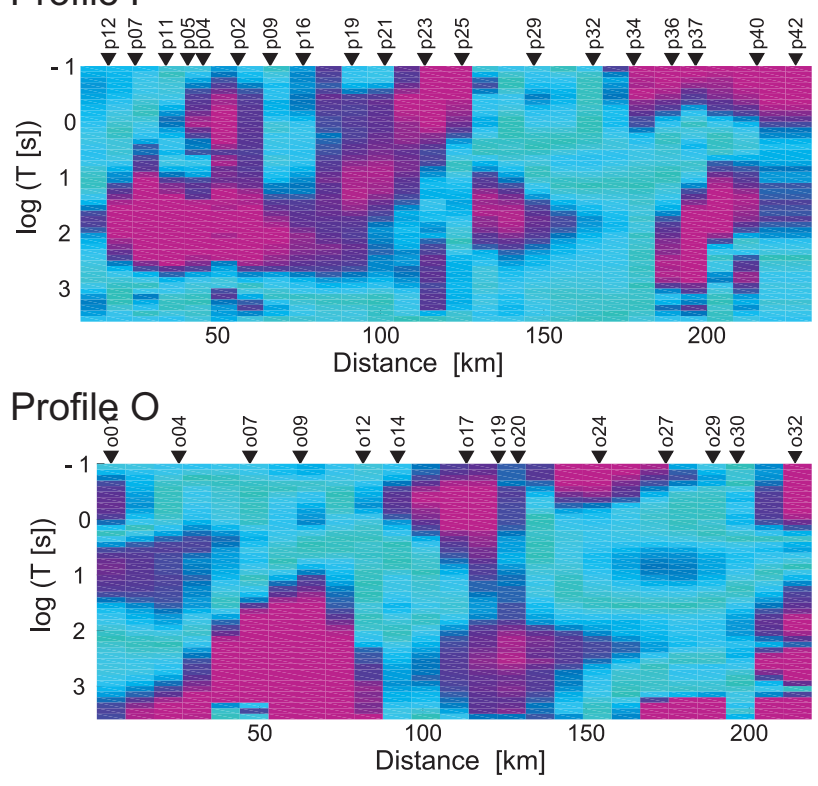

Profile L

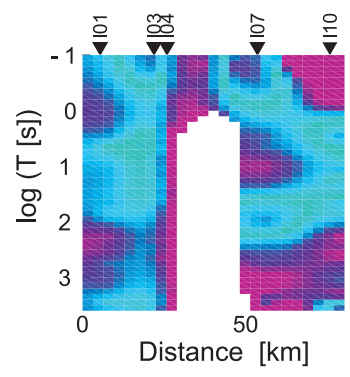

Phase difference $\left(^{\circ}\right) \mathrm{YX}$
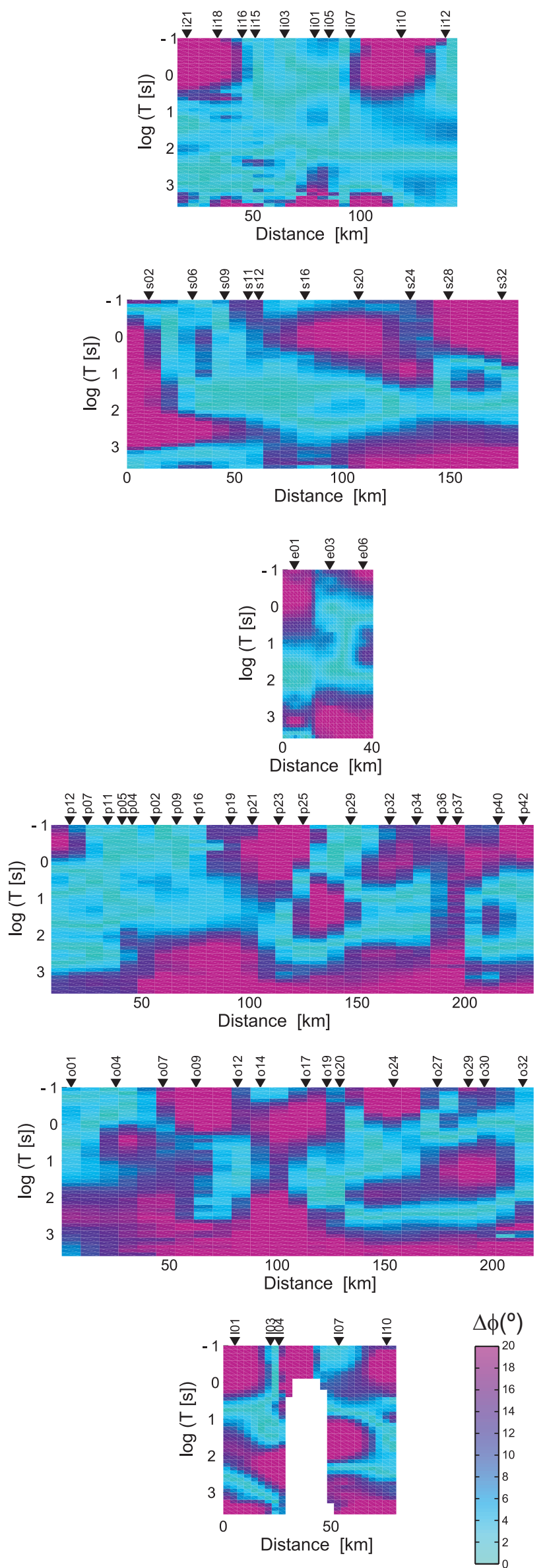

Figure 8. Pseudo-sections of the absolute phase difference between data and model responses for all the profiles. 

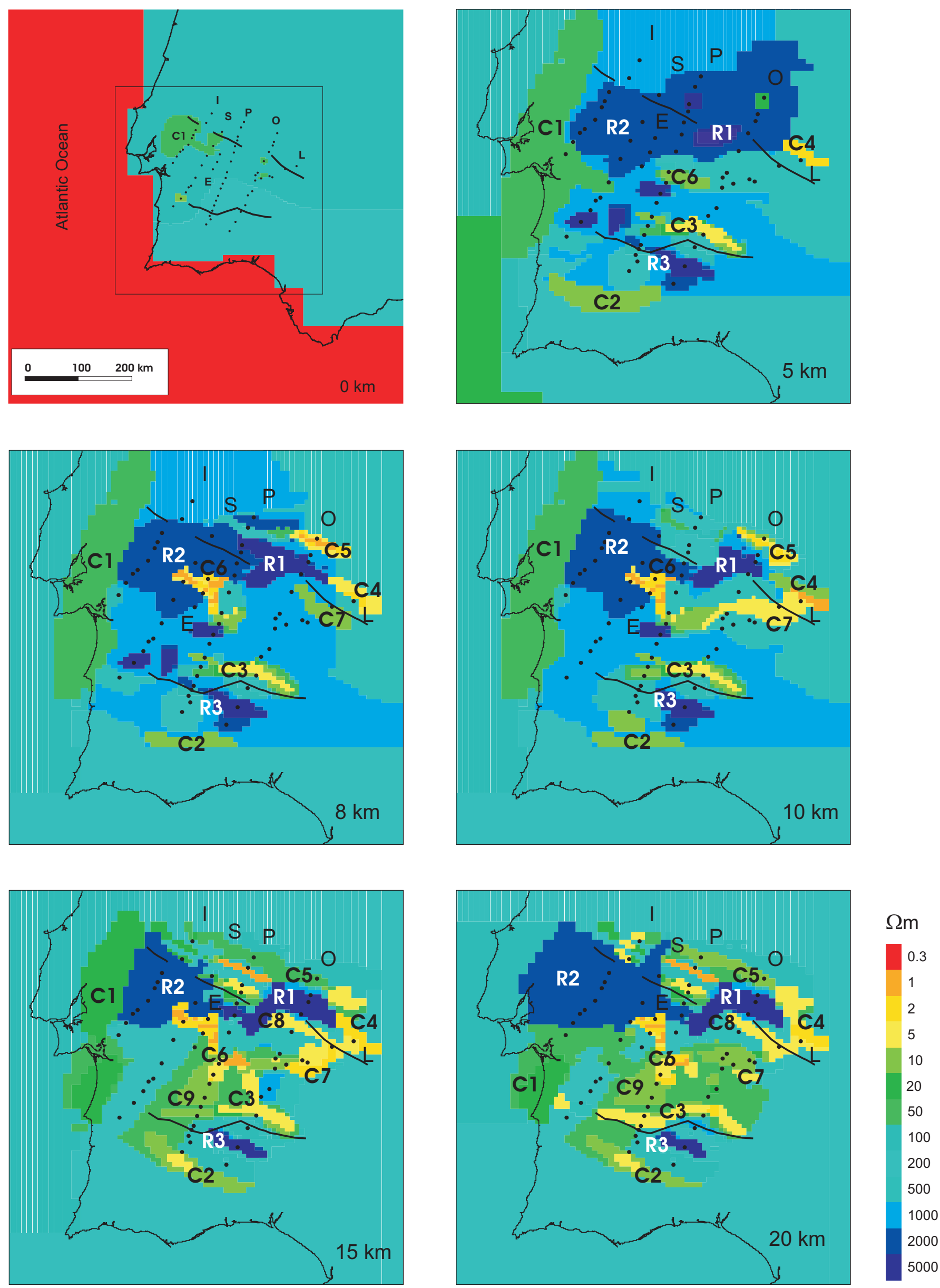

Figure 9. 3D electrical resistivity model. Plan view at different depths. The black dots indicate the location of the MT sites used for the study. The shore line and the surface occurrence of the SPZ/OMZ and OMZ/CIZ sutures (see figures 2 and 3 ) are shown to facilitate the location of the structures. 

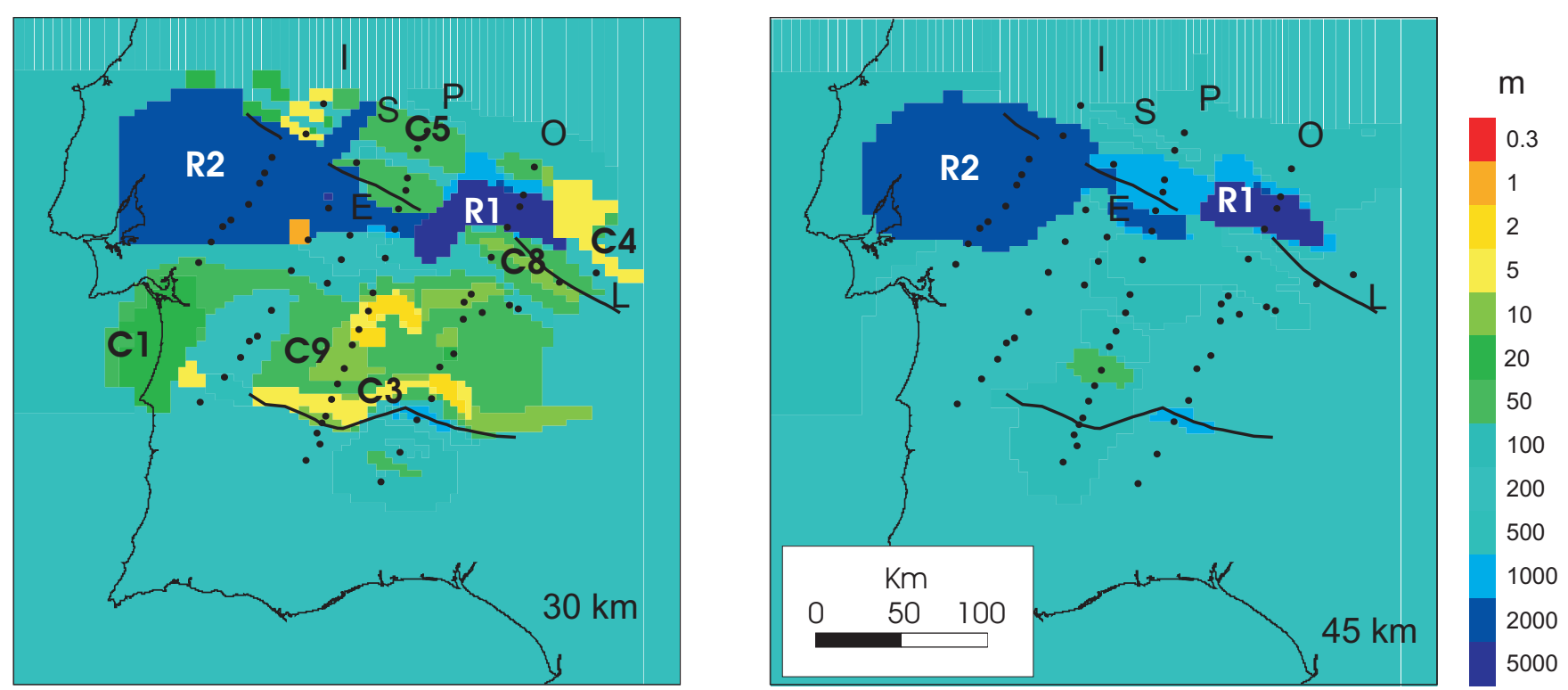

Figure 9 (cont.). 


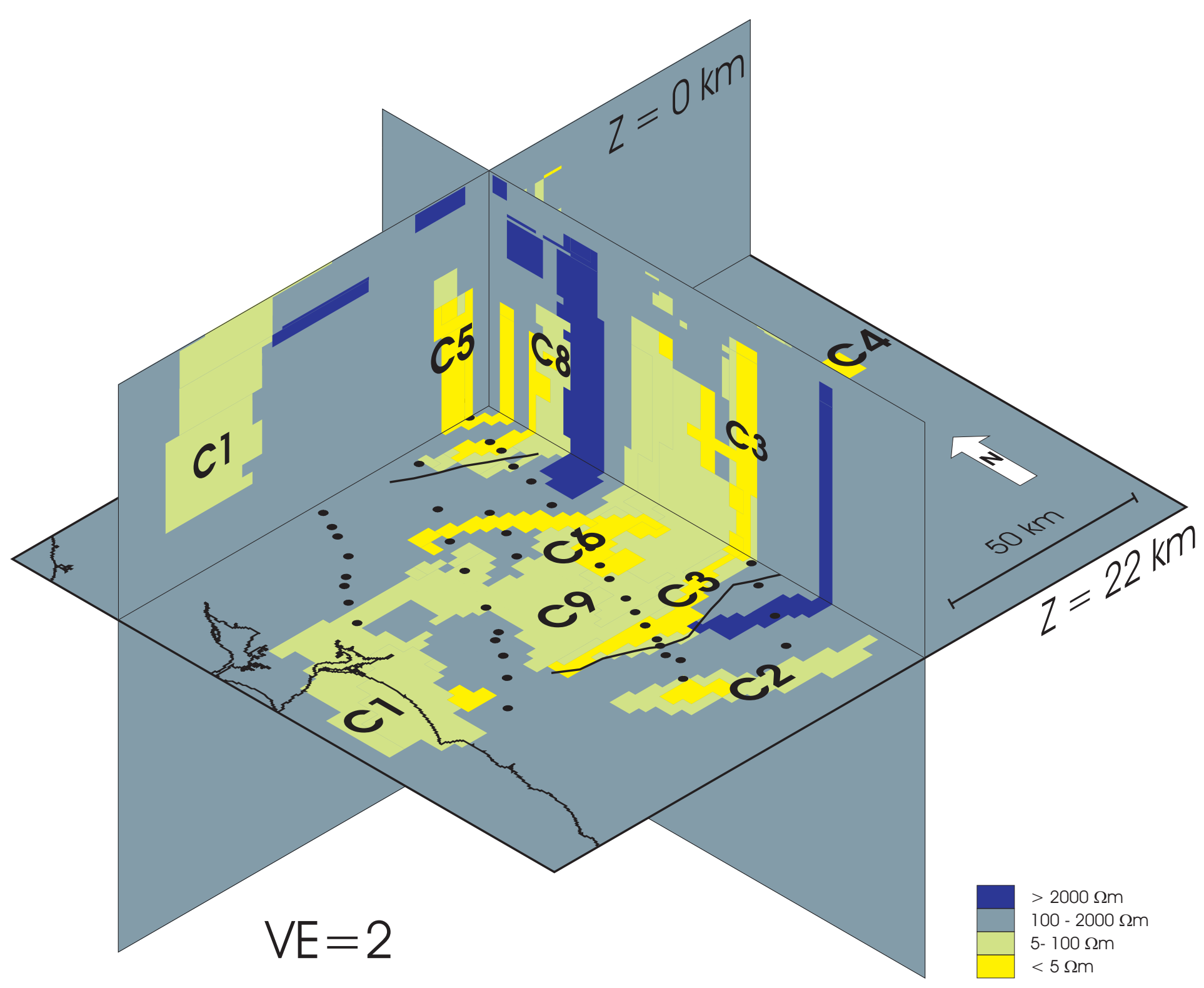

Figure 10. Plan view of the model at a depth of $22 \mathrm{~km}$ and two cross sections along a NS profile and an EW profile (Vertical exageration $=2$ ). The resistivity values have been grouped to highlight the most striking conductivity features. Conductors C1, C3 and C6 merge into the conductive layer C9. The black dots indicate the location of the MT sites. The shoreline and the surface occurrence of the sutures SPZ/OMZ and OMZ/CIZ (see figures 2 and 3) are shown to facilitate the location. 
a)

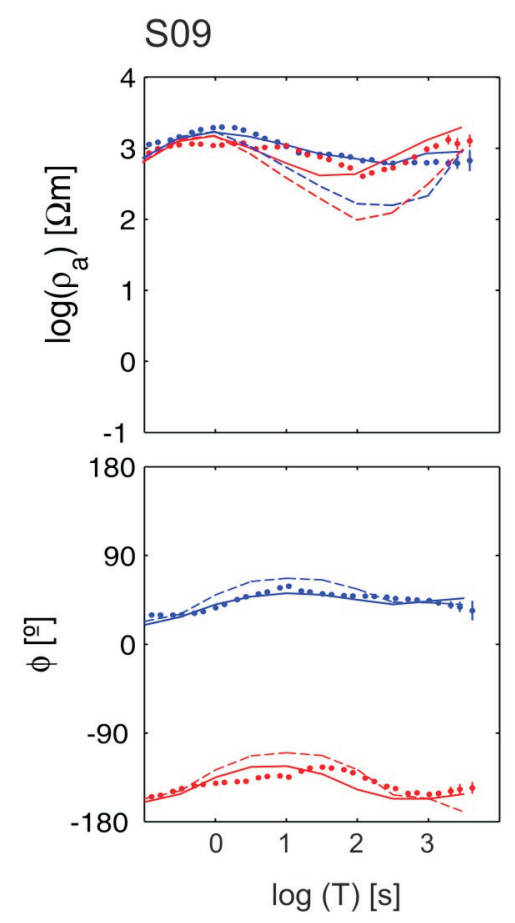

b)
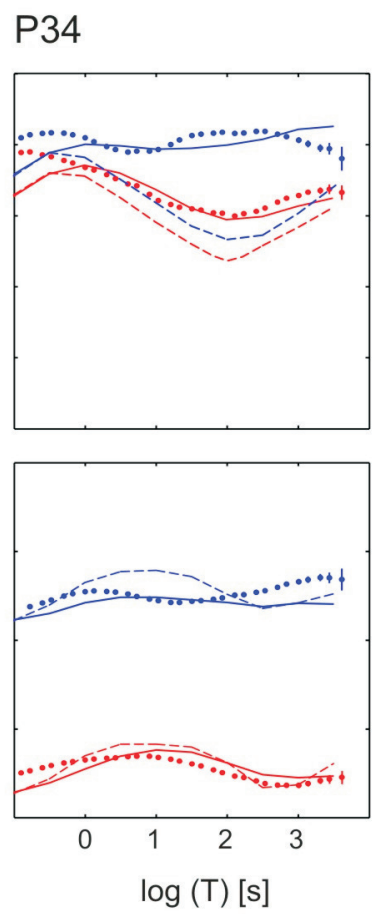

c)

d)
E06
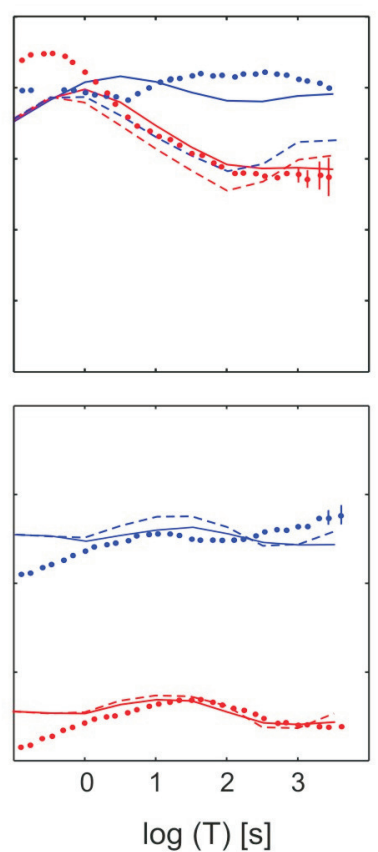
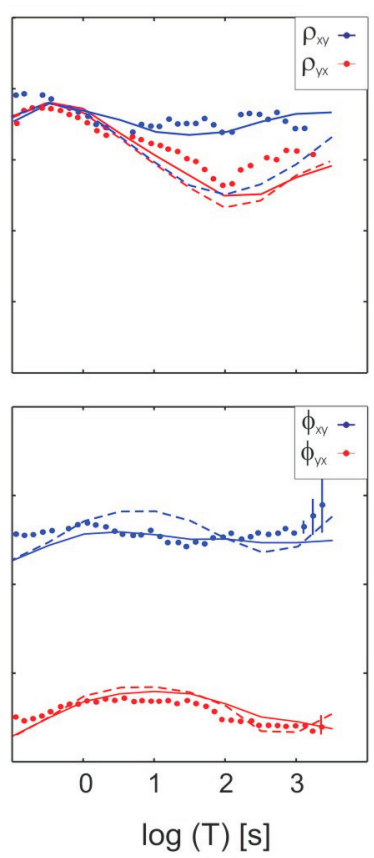

Figure 11. Data and model responses for different sensitivity tests. The dots represent the data, the solid lines the responses of the final model (Figs. 9, 10) and the dashed lines the responses of the altered models: a) Without the resisitive interruption of conductor C3 in the south of profile S. b) and c) With a $20 \Omega$ m layer extending from 10 to $30 \mathrm{~km}$ instead of the complex conductive structure. d) With conductor C6 replaced by a more extended $20 \Omega \mathrm{m}$ conductive body. 